Article

\title{
Trinuclear Oxo-Titanium Clusters: Synthesis, Structure, and Photocatalytic Activity
}

\author{
Maciej Janek, Tadeusz M. Muzioł and Piotr Piszczek * \\ Faculty of Chemistry, Nicolaus Copernicus University in Toruń, Gagarina 7, 87-100 Toruń, Poland; \\ maciejjanekk@gmail.com (M.J.); tadeuszmuziol@wp.pl (T.M.M.) \\ * Correspondence: piszczek@umk.pl; Tel.: +48-56-611-45-92
}

Received: 8 August 2019; Accepted: 24 September 2019; Published: 29 September 2019

check for updates

\begin{abstract}
The interest in titanium (IV) oxo-complexes is due to their potential application in photodegradation processes and environmental pollutants reduction. Titanium (IV) oxo-complexes (TOCs) of the general formula $\left[\mathrm{Ti}_{3} \mathrm{O}\left(\mathrm{O}^{i} \mathrm{Pr}\right)_{8}\left(\mathrm{OOCR}^{\prime}\right)_{2}\right]\left(\mathrm{R}^{\prime}=-\mathrm{C}_{13} \mathrm{H}_{9}(\mathbf{1}),-p-\mathrm{PhCl}(\mathbf{2}),-m-\mathrm{PhNO}_{2}\right.$ (3), $\left.-\mathrm{C}_{4} \mathrm{H}_{7}(4)\right)$ were synthesized and structurally characterized. The use of the different carboxylate ligands allowed modulating the optical band gaps of the produced microcrystals, which were measured via diffuse reflectance ultraviolet and visible spectroscopy (UV-Vis-DRS) and calculated using the density functional theory (DFT) method. The dispersion of TOCs (1-3) in the poly (methyl methacrylate) matrix (PMMA) led to the formation of polymer/TOCs composites, which in the next stage of our works have been applied in the photocatalytic activity estimation of synthesized trinuclear Ti(IV) oxo-complexes. Studies of the photocatalytic degradation of methylene blue (MB) induced by UV irradiation exhibit that the PMMA-TOCs composite containing (1) oxo-clusters is the most active, followed by the system containing the complex (3).
\end{abstract}

Keywords: Titanium (IV) oxo-clusters; structure; photocatalytic activity; bandgap modification; DFT calculations; polymer/inorganic composite systems

\section{Introduction}

Studies on multinuclear titanium (IV) oxo-complexes (TOCs) are interesting due to the fact that their discrete molecular structure provide insight into correlations between the composition and photophysical properties of these compounds [1,2]. Analyses of property changes in TOCs are especially important. For example, their photoinduced activity towards organic substances degradation, resulting from the similarity of these materials to $\mathrm{TiO}_{2}$ [3]. In many cases, the presence of organic ligands $\left(-\mathrm{OR},-\mathrm{O}_{2} \mathrm{CR}^{\prime}\right)$ in the structure of oxo-clusters serve both as multidentate stabilizers of $\left\{\mathrm{Ti}_{\mathrm{a}} \mathrm{O}_{\mathrm{b}}\right\}$ core (e.g. carboxylates, phosphonates), but also as a functionality provider that allows for the acquisition of the unique properties of new materials $[4,5]$. The knowledge gained based on the results of this investigation enable the rational design and the fabrication of TOCs-based materials as photocatalytic systems and their application as a molecular tool to enhance and modulate photophysical properties of the composite materials.

According to earlier reports, the unfunctionalized TOCs are characterized by a wide band gap, e.g., $3.60 \mathrm{eV}$ for $\left[\mathrm{Ti}_{8} \mathrm{O}_{8}(\mathrm{OH})_{4}\left(\mathrm{CO}_{2}\right)_{12}\right.$ ] [6] (to compare, the band gap for the rutile is 3.03 and $3.23 \mathrm{eV}$ for anatase [7]). The efficient band gap modulation arising from the core-ligands interaction is possible as a result of introduction of photoactive functionalities to the structure of TOCs, which was confirmed by numerous investigations. An excellent example has been displayed in work of Liu et al. [8], where various carboxylate ligands were introduced to labile coordination sides of hexanuclear $\left[\mathrm{Ti}_{6} \mathrm{O}_{4}\left(\mathrm{O}^{\mathrm{i} P r}\right)_{10}\left(\mathrm{O}_{3} \mathrm{P}-\mathrm{Phen}\right)_{2}(\mathrm{OAc})_{2}\right]$ complex. Authors were able to modulate band gap values of series of analogous compounds in 3.6-3.0 eV range only by the change of organic functionalities. The more 
subtle modulation method of band gap values consists in changes of the skeleton composition, while functionalized ligands are maintained. Cui et al. have shown this approach in case of 4-chlorosalicylate stabilized titanium-oxo complexes with different cluster architecture [9]. The resulting optical band gaps changed by a small value, but adequate photo-response differed as oxo-titanium skeleton played a big role in photoactive behaviour of TOCs. The last important approach to alter the characteristic of TOCs, namely the heteroatomic doping of oxo-core, is of great importance. The metal atom can be incorporated into oxo-core architecture and ligands with functionalities possessing lone electron pairs may be used to coordinate to the heteroatomic centre. Additional states introduced by these heteroatoms greatly alter electronic structure of TOCs and their photoinduced behaviour [10]. Our previous works on synthesis and structural characterization of $\left[\mathrm{Ti}_{4} \mathrm{O}_{2}\left(\mathrm{O}^{\mathrm{i}} \mathrm{Bu}\right)_{10}\left(\mathrm{O}_{2} \mathrm{CR}^{\prime}\right)_{2}\right]\left(\mathrm{R}=-\mathrm{C}_{13} \mathrm{H}_{9}\right.$, $-m-\mathrm{PhCl},-p-\mathrm{PhNH}_{2}$ and $-m-\mathrm{PhNO}_{2}$ ) oxo-complexes revealed the possibility of modulation of the band gap value of material by anchoring of the different carboxylate ligands to the $\left\{\mathrm{Ti}_{4} \mathrm{O}_{2}\right\}$ skeleton [11,12]. This type of compound was used in the fabrication of polymer/TOCs composites (PMMA/TOCs, PMMA $=$ poly (methyl methacrylate), TOCs $=\left\{\mathrm{Ti}_{4} \mathrm{O}_{2}\right\}$ clusters), which exhibited promising photocatalytic activity in UV photoinduced degradation processes of methylene blue (MB). Such factors as: (a) low band gap value, (b) $n$-doped character of the compound, (c) ability to generate Ti(III) states upon irradiation and(d) dispersion of titanium oxo-complex nanocrystals in polymer matrix, had a big impact on photocatalytic properties of materials. Considering the results of carried out works, it should be noted that further studies on synthesis and properties of the novel polymer/TOCs-based composite materials, requires the precise analysis of cores size tailoring and their architecture.

Continuing earlier works we have focused on the synthesis of trinuclear Ti (IV) oxo-complexes, characterization of their structure and the estimation of their photocatalytic activity (analysed in the form of polymer/TOCs system). The synthesis and structure of trinuclear Ti (IV) oxo-clusters have been earlier described by Boyle et al. [13], and Mijatovic et al. [14], and Czakler et al. [15]. Simultaneously, discussing the stepwise assembly processes of larger $\left\{\mathrm{Ti}_{\mathrm{a}} \mathrm{O}_{\mathrm{b}}\right\}$ cores Schubert suggested that oxo-complex with the $\left\{\mathrm{Ti}_{3} \mathrm{O}\right\}$ core is the basic unit, which in proper conditions leads to the formation of $\left[\mathrm{Ti}_{\mathrm{a}} \mathrm{O}_{\mathrm{b}}(\mathrm{OR})_{\mathrm{c}}\left(\mathrm{O}_{2} \mathrm{CR}^{\prime}\right)_{4 \mathrm{a}-2 \mathrm{~b}-\mathrm{c}}\right]$ clusters [16]. In our research, we have decided to carry out syntheses of $\left[\mathrm{Ti}_{3} \mathrm{O}\left(\mathrm{O}^{\mathrm{i}} \mathrm{Pr}\right)_{8}\left(\mathrm{O}_{2} \mathrm{CR}^{\prime}\right)_{2}\right]$ systems using the novel group of organic acids, i.e. HOOCR', $\mathrm{R}^{\prime}=$ $-\mathrm{C}_{13} \mathrm{H}_{9},-\mathrm{p}-\mathrm{PhCl}$, and $-\mathrm{m}-\mathrm{PhNO}_{2},-\mathrm{C}_{4} \mathrm{H}_{7}$, which were not studied yet in terms of this topic. The aim of our studies was to determine the influence of the organic acid type on the core $\left\{\mathrm{Ti}_{3} \mathrm{O}\right\}$ structure, on the size of the energy band gap, as well as on the photocatalytic activity of isolated trinuclear $\mathrm{Ti}(\mathrm{IV})$ oxo-clusters. The estimation of this effect is especially important for the future application of polymer materials enriched with Ti (IV) oxo-complexes, as the photocatalytic systems used in the biological/organic pollutants degradation.

\section{Materials and Methods}

\subsection{Materials}

Titanium(IV) isopropoxide (Aldrich, St. Louis, MO, USA), 4-chlorobenzoic acid (Aldrich, St. Louis, MO, USA), 3-nitrobenzoic acid (Aldrich, St. Louis, MO, USA), 3,3-dimethylacrylic acid Aldrich, St. Louis, MO, USA), and 9-fluorenecarboxylic acid (Organic Acro, Geel, Belgium) were purchased commercially and were used without further purification. Tetrahydrofuran (THF) was distilled before using. Standard Schlenk techniques were used for synthesis under an inert gas atmosphere.

\subsection{Synthesis}

The synthesis of $\left[\mathrm{Ti}_{3} \mathrm{O}\left(\mathrm{O}^{\mathrm{i} P r}\right)_{8}\left(\mathrm{O}_{2} \mathrm{CC}_{13} \mathrm{H}_{9}\right)_{2}\right](\mathbf{1}) .0 .184 \mathrm{~g}$ of 9-fluorenecarboxylic acid $(0.875 \mathrm{mmol})$ was added to the solution of $1 \mathrm{ml}$ titanium (IV) isopropoxide ( $3.5 \mathrm{mmol}$ ) in $2 \mathrm{ml}$ of THF/PrOH (1:1). Reactants underwent rapid reaction leading to clear brownish solution. The solution was left for crystallization. Crystalline product was collected after 3 days. The yield basing on acid: $74 \%$ ( $0.33 \mathrm{~g})$. Anal. Calc. for $\mathrm{C}_{50} \mathrm{H}_{74} \mathrm{O}_{13} \mathrm{Ti}_{3}$ : C, 58.49; $\mathrm{H}, 7.26$. Found: $\mathrm{C}, 58.76 ; \mathrm{H}, 7.16$. 
The synthesis of $\left[\mathrm{Ti}_{3} \mathrm{O}\left(\mathrm{O}^{\mathrm{i}} \mathrm{Pr}\right)_{8}\left(\mathrm{O}_{2} \mathrm{CC}_{6} \mathrm{H}_{4} \mathrm{Cl}\right)_{2}\right]$ (2). $0.137 \mathrm{~g}$ of 4-chlorobenzoic acid (0.875 mmol) was added to the solution of $1 \mathrm{ml}$ titanium(IV) isopropoxide ( $3.5 \mathrm{mmol}$ ) in $2 \mathrm{ml}$ of THF/ $\mathrm{PrOH}(1: 1)$, leading to a colourless solution. The solution was left for crystallization. Evaporation under inert gas atmosphere led to crystals suitable for $\mathrm{X}$-ray diffraction experiment. The yield basing on acid: $82 \%$ (0.34 g). Anal. Calc. for $\mathrm{C}_{38} \mathrm{H}_{64} \mathrm{O}_{13} \mathrm{Cl}_{2} \mathrm{Ti}_{3}: \mathrm{C}, 48.38 ; \mathrm{H}, 6.84$. Found: $\mathrm{C}, 49.12 ; \mathrm{H}, 6.64$.

The synthesis of $\left[\mathrm{Ti}_{3} \mathrm{O}\left(\mathrm{O}^{\mathrm{i}} \mathrm{Pr}\right)_{8}\left(\mathrm{O}_{2} \mathrm{CC}_{6} \mathrm{H}_{4} \mathrm{NO}_{2}\right)_{2}\right]$ (3). $0.146 \mathrm{~g}$ of 3-nitrobenzoic acid (0.875 mmol) was added to the solution of $1 \mathrm{ml}$ titanium (IV) isopropoxide (3.5 mmol) in $2 \mathrm{ml}$ of THF/ $\mathrm{PrOH}(1: 1)$, leading to a weak yellow solution. The solution was left for crystallization. Slow evaporation under an inert gas atmosphere led to crystals suitable for $\mathrm{X}$-ray diffraction experiment. The yield basing on acid: $67 \%$ (0.28 g). Anal. Calc. for $\mathrm{C}_{38} \mathrm{H}_{64} \mathrm{O}_{17} \mathrm{~N}_{2} \mathrm{Ti}_{3}: \mathrm{C}, 47.32 ; \mathrm{H}, 6.69 ; \mathrm{N}, 2.90$. Found: 58.25; $\mathrm{H}, 6.94 ; \mathrm{N}, 2.58$.

The synthesis of $\left[\mathrm{Ti}_{3} \mathrm{O}\left(\mathrm{O}^{\mathrm{i}} \mathrm{Pr}\right)_{8}\left(\mathrm{O}_{2} \mathrm{CC}_{4} \mathrm{H}_{7}\right)_{2}\right]$ (4). $0.088 \mathrm{~g}$ of 3,3 dimethylacrylic acid $(0.875 \mathrm{mmol})$ was added to the solution of $1 \mathrm{ml}$ titanium(IV) isopropoxide ( $3.5 \mathrm{mmol}$ ) in $2 \mathrm{ml}$ of THF/ $\mathrm{PrOH}$ (1:1), leading to a colourless solution, which was left for crystallization. Slow evaporation under an inert gas atmosphere led to crystals. The yield basing on acid: $78 \%(0.28 \mathrm{~g})$. Anal. Calc. for $\mathrm{C}_{34} \mathrm{H}_{70} \mathrm{O}_{13} \mathrm{Ti}_{3}: \mathrm{C}_{\text {, }}$ 58.49; H, 7.26. Found: C, 58.76; H, 7.16.

\subsection{Analytical Procedures}

The vibrational spectra of synthesized compounds were recorded using the Perkin Elmer Spectrum 2000 FT-IR spectrometer $\left(400-4000 \mathrm{~cm}^{-1}\right.$ range, KBr pellets, Spectrum2000, PerkinElmer Inc., Waltham, MA, USA) and the RamanMicro 200 Perkin Elmer spectrometer (PerkinElmer Inc., Waltham, MA, USA) $(1=785 \mathrm{~nm})$. The solid state optical diffuse-reflection experiment was carried out on the Jasco V-750 Spectrophotometer (Jasco Corporation, Tokyo, Japan) equipped with an integrating sphere for diffuse reflectance spectroscopy. Spectralonßwas used as the DRS refference sample. Elemental analyses were performed on Elemental Analyser vario Macro CHN (Elementar Analysensysteme $\mathrm{GmbH}$, Langenselbold, Germany). The dispersion of nano/microcrystals in polymer matrix was estimated using a Quanta field emission scanning electron microscope (FESEM, Quanta 3D FEG, Huston, TX, USA).

\subsection{X-Ray Crystalography Study}

For single crystals, the diffraction data of (2) and (3) were collected using BL14.3 beamline (Helmholtz Zentrum Berlin, Bessy II), radiation $\lambda=0.89429 \AA$, at liquid nitrogen temperature, whereas for (1) the diffraction experiment was performed at room temperature, using Oxford Sapphire CCD diffractometer, MoK $\alpha$ radiation $\lambda=0.71073 \AA$. The data were processed using CrysAlis [17], $x d s a p p$ [18], XDS [19], and the numerical absorption correction was applied for all crystals. The structures of all complexes were solved by the direct methods and refined with full-matrix least-squares procedure on F2 (SHELX-97 [20]). All heavy atoms were refined with anisotropic displacement parameters. The positions of hydrogen atoms were assigned at calculated positions with thermal displacement parameters fixed to a value of $20 \%$ or $50 \%$ higher than those of the corresponding carbon atoms. For (2) some constraints (ISOR for C15 atom) were applied. In (2) the alternate positions were found only for an aliphatic chain of O11 -O Pr. All figures were prepared in DIAMOND [21] and ORTEP-3 [22]. The results of the data collections and refinement are summarized in Table 1.

Table 1. The selected crystal data and structure refinements for $\left[\mathrm{Ti}_{3} \mathrm{O}\left(\mathrm{O}^{\mathrm{i}} \mathrm{Pr}\right)_{8}\left(\mathrm{O}_{2} \mathrm{CR}^{\prime}\right)_{2}\right]\left(\mathrm{R}^{\prime}=p-\mathrm{PhCl}(\mathbf{2})\right.$, $\left.m-\mathrm{PhNO}_{2}(3)\right)$.

\begin{tabular}{ccc}
\hline Parameters & $\mathbf{( 2 )}$ & $\mathbf{( 3 )}$ \\
\hline Empirical formula & $\mathrm{C}_{38} \mathrm{H}_{64} \mathrm{Cl}_{2} \mathrm{O}_{13} \mathrm{Ti}_{3}$ & $\mathrm{C}_{38} \mathrm{H}_{64} \mathrm{~N}_{2} \mathrm{O}_{17} \mathrm{Ti}_{3}$ \\
Formula weight $[\mathrm{g} / \mathrm{mol}]$ & 943.49 & 964.61 \\
Temperature $[\mathrm{K}]$ & $100(2)$ & $100(2)$ \\
Wavelength $[\AA]$ & 0.89429 & 0.89429 \\
Space group & Triclinic, $\mathrm{P}-1$ & Monoclinic, $\mathrm{P} 21 / \mathrm{n}$ \\
\hline
\end{tabular}


Table 1. Cont.

\begin{tabular}{|c|c|c|}
\hline Parameters & (2) & (3) \\
\hline $\begin{array}{l}\text { Unit cell dimensions }[\AA] \text { and } \\
\text { angles }\left[{ }^{\circ}\right]\end{array}$ & $\begin{array}{c}A=10.398(2) b=11.973(2) c=20.435(4) \alpha= \\
77.50(3) \beta=80.65(3) \gamma=71.71(3)\end{array}$ & $\begin{array}{l}\mathrm{A}=13.2512(3) \mathrm{B}=22.5559(4) \mathrm{c}= \\
41.475(8) \beta=92.632(2) \alpha=\gamma=90\end{array}$ \\
\hline Volume [A3] & $2346.1(10)$ & $4655.00(16)$ \\
\hline Z, Calculateddensity $\left[\mathrm{Mg} / \mathrm{m}^{3}\right]$ & $2,1.336$ & $4,1.376$ \\
\hline Reflectionscollected & 33227 & 63481 \\
\hline Independent reflections & $8434[\mathrm{R}(\mathrm{int})=0.0252]$ & $9408[R($ int $)=0.0340]$ \\
\hline Completeness to theta $=32.451^{\circ}$ & $89.0 \%$ & $99.0 \%$ \\
\hline Data/restraints/parameters & $8434 / 6 / 515$ & $9408 / 0 / 541$ \\
\hline Goodness-of-fit on F2 & 1.057 & 1.050 \\
\hline Final $\mathrm{R}$ indices [I > 2sigma(I)] & $\mathrm{R}_{1}^{\mathrm{a}}=0.0329, \mathrm{wR}_{2} \mathrm{~b}=0.0843$ & $\mathrm{R}_{1}^{\mathrm{a}}=0.0293, \mathrm{wR}_{2}{ }^{\mathrm{b}}=0.0812$ \\
\hline
\end{tabular}

\subsection{Preparation and Photocatalytic Activity Studies of Composites}

In order to obtain composite (PMMA/TOCs) foils with $20 w t . \%$ of trinuclear TOCs (1) (3), the following procedure was applied: (a) $1 \mathrm{~g}$ of poly (methyl methacrylate) (PMMA) was dissolved in THF $(10 \mathrm{ml}) ;(\mathrm{b})$ a mixture of $0.25 \mathrm{~g}$ of TOCs (1-3) in $2 \mathrm{ml}$ of THF was added to the clear stirring solution (a) and stirred for $30 \mathrm{~min}$; (c) the resulting solution was poured into a glass Petri dish and left for 2 days for solvent evaporation; (d) the composite foil was collected and prepared for a photocatalytic activity experiments. In our works we have focused in studies of (1-3) complexes of carboxylate ligands similar to these which are used in our earlier photocatalytic experiments with the use of $\left\{\mathrm{Ti}_{4} \mathrm{O}_{2}\right\}$ cores [12].

$8 \times 8 \mathrm{~mm}$ composite foil samples were prepared for every photocatalytic activity test, put into the bottom of quartz cuvettes and covered with $3 \mathrm{ml}$ of methylene blue solution $\left(\mathrm{c}=1.0 \times 10^{-5} \mathrm{M}\right)$. Samples in cuvettes were irradiated with UV light source (18 W, range of 340-410 nm with maximum at $365 \mathrm{~nm}$ ), being located $20 \mathrm{~cm}$ above the irradiation system. Absorbance values at $664 \mathrm{~nm}$ were measured every 24 hours for every sample.

In order to evaluate MB degradation kinetics, the Langmuir-Hinshelwood reaction mechanism was assumed [23]. For low concentrations $c$ the relation simplifies as follows:

$$
r=-d c / d t=k_{\operatorname{deg}} K c /(1+K c) \approx k_{\operatorname{deg}} K c=k_{\text {obs }} c
$$

where $c$ is a methylene blue concentration at a given time $t, k_{\mathrm{deg}}$ is the rate constant of methylene blue, decomposition on the foil surface, $K$ describes the reactant adsorption-desorption process, and $k_{\mathrm{obs}}$ is a pseudo-first order observed rate constant.

The slope of the following relation gives the apparent pseudo-first order rate constant:

$$
-\ln \left(c / c_{0}\right)=k_{o b s} t
$$

where $c_{0}$ is an initial concentration of $\mathrm{MB}, c$ is a $\mathrm{MB}$ concentration at a given time $t$, and $k_{\mathrm{obs}}$ is a pseudo-first order observed rate constant.

The MB decolorization percent was calculated using the following formula:

$$
\% M B \text { decolorization }=\left(c_{0}-c_{t} / c_{0}\right) \cdot 100
$$

where $c_{0}$ is an initial concentration of $\mathrm{MB}, c$ is a $\mathrm{MB}$ concentration at a given time $t$ [24].

\subsection{The Computational Details}

The crystal structures were used as a starting point of the geometry optimization stage, with exception of isopropyl groups, which were substituted with methyl groups to reduce the cost of calculations. Gaussian09 packages with B3LYP functional and 6-31G (d) basis set was used for DFT calculations [25]. The converged structures were confirmed as true local minima at the potential energy surface by no imaginary frequencies criterion. DOS plots were made with the help of the GaussSum 3.0 software [26]. 


\section{Results}

\subsection{Synthesis and Structures of $\left[\mathrm{Ti}_{3} \mathrm{O}\left(\mathrm{O}^{i} \mathrm{Pr}\right)_{8}\left(\mathrm{O}_{2} \mathrm{CR}^{\prime}\right)_{2}\right]$ clusters}

The (1-4) oxo-complexes were synthesized in the direct reaction of titanium (IV) isopropoxide and organic acids in 4:1 alkoxide/acid molar ratio in 1:1 THF/PrOHmixture as a solvent, using standard Schlenk techniques under an argon atmosphere and room temperature (RT). The following organic acids were used in our experiments: 9 fluorenecoarboxylic acid $\left(\mathrm{HOOCC}_{13} \mathrm{H}_{9}\right)$, 4-chlorobenzoic acid (HOOC- $p$-PhCl), 3-nitrobenzoic acid ( $\left.\mathrm{HOOC}-m-\mathrm{PhNO}_{2}\right)$, and 3,3-dimethylacrylic acid $\left(\mathrm{HOOCC}_{4} \mathrm{H}_{7}\right)$. The slow evaporation of the reaction liquors under an inert gas atmosphere (3-5 days), led to the isolation of crystalline products, which depending to the used organic acid were labelled as $(\mathbf{1})\left(R^{\prime}=\right.$ $\left.-\mathrm{C}_{13} \mathrm{H}_{9}\right),(2)\left(\mathrm{R}^{\prime}=-p-\mathrm{PhCl}\right),(3)\left(\mathrm{R}^{\prime}=-m-\mathrm{PhNO}_{2}\right)$, and $(4)\left(\mathrm{R}^{\prime}=-\mathrm{C}_{4} \mathrm{H}_{7}\right)$, respectively. Single crystal $\mathrm{X}-$ ray diffraction studies revealed that quality of only (2) and (3) crystals were adequate to solve and refine their structure. The quality of the obtained (1) and (4) reaction products did not allow for determining of their structure by X-ray diffraction method and required the use of spectroscopic methods for this purpose.

Analysis of diffraction data collected for (2) and (3) proved the formation $\left[\mathrm{Ti}_{3} \mathrm{O}\left(\mathrm{O}^{\mathrm{i}} \mathrm{Pr}\right)_{8}\left(\mathrm{O}_{2} \mathrm{CR}^{\prime}\right)_{2}\right]$ complexes $\left(\mathrm{R}^{\prime}=-p-\mathrm{PhCl}(2),-m-\mathrm{PhNO}_{2}(3)\right)$, which central part consists of $\mu_{3}-\mathrm{O}$ bridges linking by three $\mathrm{Ti}(\mathrm{IV})$ atoms in distorted trigonal planar $\left\{\mathrm{Ti}_{3} \mathrm{O}\right\}$ core. Two $\left(\mu_{2}-\mathrm{O}^{\mathrm{i}} \mathrm{Pr}\right)$ bridges, two syn-syn carboxylate groups, and eight terminal alkoxide ligands stabilize trinuclear titanium oxo-core, as it is shown in Figure 1. The selected bonds lengths and angles, which were found in structures of (2) and (3) are listed in Table 2. The coordination spheres of three titanium atoms showed that: (a) Ti1 and Ti2 are found in octahedral environment, whereas Ti3 is coordinatively unsaturated with $\tau_{5}$ being 0.65 and 0.64 for (2) and (3), respectively ( $\tau_{5}$ : the parameter defined as (alpha-beta)/60 with alpha and beta being the largest angles in the coordination sphere [27]), (b) their coordination spheres content is different being $\operatorname{Ti}\left(\mu_{3}-\mathrm{O}\right)(\mu-\mathrm{OR})_{2}\left(\mu-\mathrm{OOCR}^{\prime}\right)(\mathrm{OR})_{2}, \mathrm{Ti}\left(\mu_{3}-\mathrm{O}\right)(\mu-\mathrm{OR})(\mu-\mathrm{OOCR})_{2}(\mathrm{OR})_{2}$ and $\mathrm{Ti}\left(\mu_{3}-\mathrm{O}\right)(\mu-\mathrm{OR})(\mu-\mathrm{OOCR})(\mathrm{OR})_{2}$ for Ti1, Ti2 and Ti3 atoms, respectively. Comparing the structural data of these complexes allows tracing the carboxylate group's kind influence on the geometry of the $\left\{\mathrm{Ti}_{3} \mathrm{O}\right\}$ core, which may be associated with their photocatalytic activity. According to earlier reports concerning photoactivity of Ti(IV) oxo-clusters, the possible changes of titanium-oxo bridges angles should be noted, which can be responsible for the facilitation of the photocatalytic process [28].

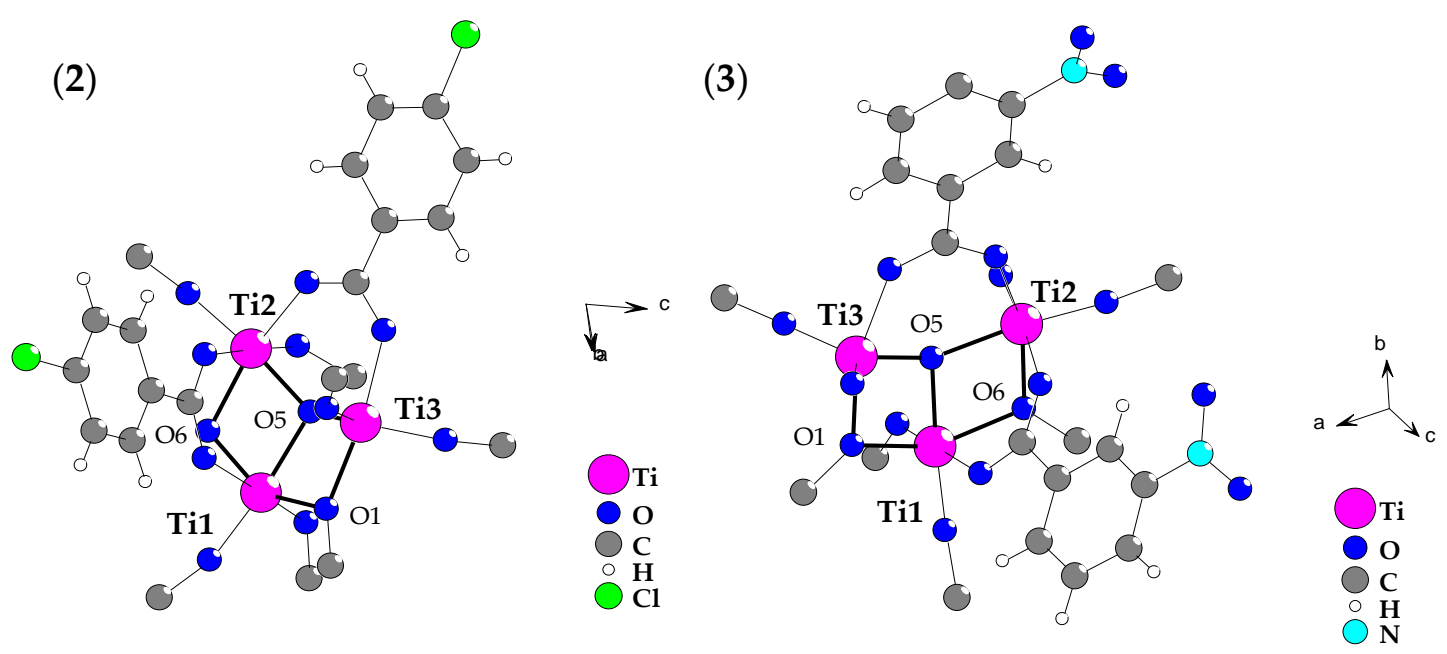

Figure 1. Structure of $\left\{\mathrm{Ti}_{3} \mathrm{O}\right\}$ core, which was found in $\left[\mathrm{Ti}_{3} \mathrm{O}(\mathrm{OR})_{8}\left(\mathrm{O}_{2} \mathrm{CR}^{\prime}\right)_{2}\right]\left(\mathrm{R}={ }^{\mathrm{i}} \mathrm{Pr}, \mathrm{R}^{\prime}=\mathrm{PhCl}(2)\right.$, $\mathrm{PhNO}_{2}$ (3) complexes (crystallographic ball-stick scheme). For clarity, the terminal alkoxide groups are omitted. 
Table 2. Selected bond lengths $(\AA)$ and angles $\left({ }^{\circ}\right)$ of $\left[\mathrm{Ti}_{3} \mathrm{O}\left(\mathrm{O}^{\mathrm{i}} \mathrm{Pr}\right)_{8}\left(\mathrm{O}_{2} \mathrm{CR}^{\prime}\right)_{2}\right]\left(\mathrm{R}^{\prime}=-p-\mathrm{PhCl}\right.$ (2), $-m-\mathrm{PhNO}_{2}$ (3).

\begin{tabular}{|c|c|c|c|}
\hline \multicolumn{2}{|c|}{$\begin{array}{c}\text { Parameter } \\
\text { Distances [̊] }\end{array}$} & \multirow{2}{*}{$\begin{array}{c}\text { (2) } \\
3.0787(12)\end{array}$} & \multirow{2}{*}{$\begin{array}{c}\text { (3) } \\
3.0734(3)\end{array}$} \\
\hline $\mathrm{Ti}-\mathrm{Ti}$ & Ti1-Ti3 & & \\
\hline & Ti1-Ti2 & $3.1455(9)$ & $3.1557(3)$ \\
\hline & Ti2-Ti3 & $3.6297(13)$ & $3.6649(3)$ \\
\hline \multirow[t]{3}{*}{$\mathrm{Ti}-\left(\mu_{3}-\mathrm{O}\right)$} & Ti1-O5 & $2.0165(14)$ & $2.0016(9)$ \\
\hline & Ti2-O5 & $2.0012(14)$ & $1.9953(10)$ \\
\hline & Ti3-O5 & $1.8561(15)$ & $1.8513(9)$ \\
\hline \multirow[t]{4}{*}{$\mathrm{Ti}-\left(\mu_{2}-\mathrm{OR}\right)$} & Ti1-O1 & $2.0210(15)$ & $2.0177(10)$ \\
\hline & Ti1-O6 & $2.0058(14)$ & $2.0227(10)$ \\
\hline & Ti2-O6 & $2.0097(14)$ & $2.0139(9)$ \\
\hline & Ti3-O1 & $1.9921(14)$ & 1.9806(9) \\
\hline \multirow[t]{6}{*}{ Ti-OR } & Ti1-O11 & $1.7921(14)$ & $1.7836(10)$ \\
\hline & Ti1-O16 & $1.8019(15)$ & $1.8147(10)$ \\
\hline & Ti2-O21 & $1.8125(15)$ & $1.7834(10)$ \\
\hline & Ti2-O26 & $1.7997(15)$ & $1.8039(10)$ \\
\hline & Ti3-O31 & $1.7875(16)$ & $1.7942(11)$ \\
\hline & Ti3-O36 & $1.7835(16)$ & $1.7505(11)$ \\
\hline \multirow[t]{4}{*}{ Ti-O (carb) } & Ti1-O51 & $2.1807(16)$ & $2.1834(10)$ \\
\hline & Ti2-O52 & $2.1242(16)$ & $2.1560(10)$ \\
\hline & Ti2-O42 & $2.0686(14)$ & $2.0705(9)$ \\
\hline & Ti3-O41 & $2.0584(15)$ & $2.0644(10)$ \\
\hline \multirow[t]{4}{*}{$\mathrm{O}-\mathrm{C}$ (carb) } & O41-C42 & $1.255(2)$ & $1.2605(18)$ \\
\hline & $\mathrm{O} 42-\mathrm{C} 42$ & $1.263(2)$ & $1.2573(17)$ \\
\hline & O51-C52 & $1.262(2)$ & $1.2551(17)$ \\
\hline & O52-C52 & $1.265(2)$ & $1.2631(17)$ \\
\hline \multicolumn{4}{|c|}{ Angles [deg] } \\
\hline \multirow[t]{3}{*}{$\mathrm{Ti}-\left(\mu_{3}-\mathrm{O}\right)-\mathrm{Ti}$} & Ti3-O2-Ti2 & $140.41(7)$ & $144.61(5)$ \\
\hline & Ti3-O2-Ti1 & $105.23(6)$ & $105.75(5)$ \\
\hline & Ti2-O2-Ti1 & 103.05(6) & $104.28(4)$ \\
\hline \multirow{2}{*}{$\mathrm{Ti}-\left(\mu_{2}-\mathrm{OR}\right)-\mathrm{Ti}$} & Ti1-O1-Ti3 & $100.20(6)$ & $100.47(4)$ \\
\hline & Ti1-O6-Ti2 & $103.13(6)$ & $102.84(4)$ \\
\hline \multirow[t]{2}{*}{$\mathrm{O}-\mathrm{C}-\mathrm{O}$ (carb) } & $\mathrm{O} 41-\mathrm{C} 42-\mathrm{O} 42$ & 126.12(17) & $126.94(12)$ \\
\hline & O51-C52-O52 & $125.69(18)$ & $126.69(13)$ \\
\hline
\end{tabular}

The comparison of $\mathrm{Ti}-\left(\mu_{3}-\mathrm{O}\right)$ distances and $\mathrm{Ti}-\left(\mu_{3}-\mathrm{O}\right)-\mathrm{Ti}$ angles revealed similarities between geometry of oxo-bridges in the structure of (2) and (3) complexes. It should be noted that Ti- $\left(\mu_{3}-\mathrm{O}\right)$ bonds are much shorter for five-coordinated Ti3 atoms found in heavily distorted trigonal bipyramidal surrounding and the Ti3-O5-Ti2 angle is also significantly bigger than two remaining Ti-O5-Ti angles. The shift of the oxygen atom relative the plane formed by the three atoms of titanium of $\left\{\mathrm{Ti}_{3}-\mathrm{O}\right\}$ core, being $0.36 \AA$ for (2) and $0.24 \AA$ for (3), is especially interesting. However, this oxo-anion is buried in the hydrophobic cavity between three ${ }^{\mathrm{i}} \mathrm{Pr}$ groups and is not involved into intermolecular interactions.

\subsection{Spectral Characterization of Trinuclear Ti(IV) Oxocomplexes}

Due to the low crystals quality of (1) and (4) oxo-clusters, their structures were determined on the basis of IR and Raman spectra analysis. The following spectral ranges were analyzed: (a) below $800 \mathrm{~cm}^{-1}$, (b) 1400-1700 $\mathrm{cm}^{-1}$, and (c) $900-1050 \mathrm{~cm}^{-1}$, where appears the bands derived to stretching and bending vibrations of $\left\{\mathrm{Ti}_{3} \mathrm{O}\right\}$ bridges, carboxylato and alkoxide groups, coordinated to the oxo-core, respectively. The vibrational spectroscopy analysis was assisted by DFT methods. DFT calculations (B3LYP/6-31G(d) level of theory) have been carried out for studied $\left\{\mathrm{Ti}_{3} \mathrm{O}\right\}$ core linked with two carboxylate ligands ((1-4)) and stabilized by eight alkoxide groups (XYZ atom coordinates of the optimized structures are presented in Tables S1-S4). Results of these works are collected in Table 3. 
Table 3. The results of the DFT calculation of Ti-O and Ti-O-Ti frequency modes noticed for $\left\{\mathrm{Ti}_{3}-\left(\mu_{3}-\mathrm{O}\right)\right\}$ bridges of $\left[\mathrm{Ti}_{3} \mathrm{O}(\mathrm{OMe})_{8}\left(\mathrm{O}_{2} \mathrm{CR}^{\prime}\right)_{2}\right]$ clusters. TheO ${ }^{\mathrm{i}} \mathrm{Pr}$ ligands were exchanged on the OMe groups for sake of simplicity. Scaling factor of 1.0007 was applied [29].

\begin{tabular}{|c|c|c|c|c|c|c|}
\hline \multirow{2}{*}{ Complex } & \multicolumn{6}{|c|}{ Frequency of Vibrations Involved in $v_{s}\left(\mathrm{Ti}_{3}-\left(\mu_{3}-\mathrm{O}\right)\right)$ Bridge $\left(\mathrm{cm}^{-1}\right)$} \\
\hline & $v_{1}\left(\mathrm{~A}^{\prime}\right)$ & $v_{2}\left(A^{\prime}\right)$ & $v_{5}\left(\mathrm{~A}^{\prime \prime}\right)$ & $v_{3}\left(A^{\prime}\right)$ & $v_{4}\left(A^{\prime}\right)$ & $v_{6}\left(A^{\prime \prime}\right)$ \\
\hline$\left[\mathrm{Ti}_{3} \mathrm{O}(\mathrm{OMe})_{8}\left(\mathrm{O}_{2} \mathrm{CMe}\right)_{2}\right]$ & 730 & 556 & 504 & 446 & 363 & 344 \\
\hline$\left[\mathrm{Ti}_{3} \mathrm{O}(\mathrm{OMe})_{8}\left(\mathrm{O}_{2} \mathrm{CC}_{13} \mathrm{H}_{9}\right)_{2}\right]$ & 722 & 553 & 488 & 446 & 359 & 350 \\
\hline$\left[\mathrm{Ti}_{3} \mathrm{O}(\mathrm{OMe})_{8}\left(\mathrm{O}_{2} \mathrm{C}-p-\mathrm{PhCl}\right)_{2}\right]$ & 723 & 554 & - & 447 & 355 & 350 \\
\hline$\left[\mathrm{Ti}_{3} \mathrm{O}(\mathrm{OMe})_{8}\left(\mathrm{O}_{2} \mathrm{C}-m-\mathrm{PhNO}_{2}\right)_{2}\right]$ & 724 & 549 & - & 447 & 358 & 340 \\
\hline$\left[\mathrm{Ti}_{3} \mathrm{O}(\mathrm{OMe})_{8}\left(\mathrm{O}_{2} \mathrm{CC}_{4} \mathrm{H}_{7}\right)_{2}\right]$ & 717 & 544 & - & 447 & 357 & 340 \\
\hline
\end{tabular}

In our calculations, $\mathrm{O}^{\mathrm{i}} \mathrm{Pr}$ ligands were exchanged on the OMe groups for sake of simplicity, moreover the calculations for the $\left[\mathrm{T}_{\mathrm{i} 3} \mathrm{O}(\mathrm{OMe})_{8}(\mathrm{OOCMe})_{2}\right]$ cluster has been carried out as a reference system. The spectral data for above mentioned regions of infrared (IR) and Raman spectra are presented in Table 4 and Figure 2, while the whole IR and Raman spectra of studied compounds are presented as the supplementary data (Figures S1 and S2). The results of our earlier spectral studies (IR, Raman) of titanium(IV) oxo-complexes (containing the $\left\{\mathrm{Ti}_{\mathrm{a}} \mathrm{O}_{\mathrm{b}}\right\}$ moiety) revealed that the bands of very weak (vw) or middle $(\mathrm{m})$ intensity, which can be assigned to vibrations $\mu_{\mathrm{i}}-\mathrm{O}$ bridges $(\mathrm{i}-2,3,4)$ appears between 300 and $900 \mathrm{~cm}^{-1}[11,12,30,31]$. The bands registered at $480-900 \mathrm{~cm}^{-1}$ can be assigned to stretching modes of $v(\mathrm{Ti}-\mathrm{O})$ modes, while the bands at $300-480 \mathrm{~cm}^{-1}$ to bending $\delta$ (Ti-O-Ti) ones.

Table 4. frequency of bands assigned to the vibration of coordinated carboxylate groups, isopropoxide ligands, and Ti(IV)-oxo bridges $\left(\mu_{3}-\mathrm{O}\right)$ in IR and Raman spectra of studied of (1-4))complexes (vs = very strong; $\mathrm{s}=$ strong; $\mathrm{m}=$ medium; $\mathrm{w}=$ weak; $\mathrm{vw}=$ very weak; $\mathrm{b}=$ broad $)$.

\begin{tabular}{|c|c|c|c|c|c|c|c|c|}
\hline \multirow{2}{*}{ Modes } & \multicolumn{2}{|c|}{$\left[\mathrm{Ti}_{3} \mathrm{O}\left(\mathrm{O}^{\mathrm{i}} \mathrm{Pr}\right)_{8}\left(\mathrm{O}_{2} \mathrm{CC}_{13} \mathrm{H}_{9}\right)_{2}\right](1)$} & \multicolumn{2}{|c|}{$\left[\mathrm{Ti}_{3} \mathrm{O}\left(\mathrm{O}^{\mathrm{i}} \mathrm{Pr}\right)_{8}\left(\mathrm{O}_{2} \mathrm{CPhCl}\right)_{2}\right](2)$} & \multicolumn{2}{|c|}{$\left[\mathrm{Ti}_{3} \mathrm{O}\left(\mathrm{O}^{\mathrm{i}} \mathrm{Pr}\right)_{8}\left(\mathrm{O}_{2} \mathrm{CPhNO}_{2}\right)_{2}\right]$ (3) } & \multicolumn{2}{|c|}{$\left[\mathrm{Ti}_{3} \mathrm{O}\left(\mathrm{O}^{\mathrm{i}} \mathrm{Pr}\right)_{8}\left(\mathrm{O}_{2} \mathrm{CC}_{4} \mathrm{H}_{7}\right)_{2}\right](4)$} \\
\hline & IR & $\mathbf{R}$ & IR & $\mathbf{R}$ & IR & $\mathbf{R}$ & IR & $\mathbf{R}$ \\
\hline$v\left(\mathrm{NO}_{2}\right)$ & - & - & - & - & $\begin{array}{c}1617(\mathrm{w}) 1600 \\
(\mathrm{~m})\end{array}$ & $\begin{array}{c}1617(\mathrm{~m}) 1599 \\
(\mathrm{w})\end{array}$ & - & - \\
\hline$v(\mathrm{C}=\mathrm{C})$ & $1610(\mathrm{~s})$ & 1610 (vs) & - & - & - & - & $1650(\mathrm{~m})$ & $1650(\mathrm{~s})$ \\
\hline$v_{\text {as }}(\mathrm{COO})$ & $1554(\mathrm{~m})$ & $1552(\mathrm{~m})$ & $\begin{array}{c}1595 \text { (s) } 1556 \\
\text { (s) }\end{array}$ & $\begin{array}{c}1595 \text { (s) } 1554 \\
\text { (w) }\end{array}$ & $\begin{array}{c}1563(\mathrm{~m}) 1536 \\
(\mathrm{~s})\end{array}$ & $1563(\mathrm{~m})$ & 1554 (s) & $1552(\mathrm{~m})$ \\
\hline$v_{\mathrm{s}}(\mathrm{COO})$ & $1448(w)$ & $1448(\mathrm{~m})$ & $1462(\mathrm{w})$ & $1448(\mathrm{~m})$ & $1438(\mathrm{~m})$ & $1448(\mathrm{~m})$ & $1448(\mathrm{~m})$ & 1449 (s) \\
\hline $\begin{array}{c}v(\mathrm{C}-\mathrm{O}) \\
v(\mathrm{Ti}-\mathrm{OR})\end{array}$ & $\begin{array}{c}1019(\mathrm{~m}) 1009 \\
(\mathrm{~m})\end{array}$ & $\begin{array}{c}1023(\mathrm{~s}) 978 \\
(\mathrm{w})\end{array}$ & $\begin{array}{l}1015 \text { (s) } 986 \\
\text { (m) }\end{array}$ & 1026 (s) & $\begin{array}{c}1014 \text { (vs) } 989 \\
\text { (m) }\end{array}$ & $\begin{array}{c}1027 \text { (vs) } 1005 \\
\text { (s) }\end{array}$ & $1015(\mathrm{~s}) 987(\mathrm{~s})$ & $\begin{array}{c}1027 \text { (vs) } 988 \\
\text { (w) }\end{array}$ \\
\hline $\begin{array}{l}v_{\mathrm{s}}(\mathrm{CCC}) \\
v(\mathrm{Ti}-\mathrm{OR})\end{array}$ & $853(\mathrm{~m})$ & $\begin{array}{c}886(w) 856 \\
(w)\end{array}$ & $\begin{array}{c}852(\mathrm{~m}) 832 \\
(\mathrm{w})\end{array}$ & $848(\mathrm{~m}) 820(\mathrm{w})$ & $854(\mathrm{~m})$ & $856(w)$ & $\begin{array}{c}867(\mathrm{w}) 849(\mathrm{~m}) \\
833(\mathrm{w})\end{array}$ & $\begin{array}{c}856(w) 837 \\
(w)\end{array}$ \\
\hline $\begin{array}{c}\delta(\mathrm{CH})(\mathrm{Ph}) \\
v(\mathrm{Ti}-\mathrm{O})\left(\mu_{3}-\mathrm{O}\right)\end{array}$ & $740(\mathrm{~m})$ & $\begin{array}{c}747(\mathrm{~m}) 725 \\
(\mathrm{w})\end{array}$ & $770(\mathrm{~m})$ & $725(w)$ & $\begin{array}{c}765(\mathrm{w} b) 653 \\
(\mathrm{w}) 721(\mathrm{~m})\end{array}$ & $\begin{array}{c}739(\mathrm{vw}) 725 \\
(\mathrm{w})\end{array}$ & $750(w) 735(w)$ & $\begin{array}{c}753(\mathrm{w}) 723 \\
(\mathrm{vw})\end{array}$ \\
\hline$\delta(\mathrm{CCC})(\mathrm{Ph})$ & $\begin{array}{c}691(\mathrm{w}) 660(\mathrm{~m}) \\
621(\mathrm{~m})\end{array}$ & $\begin{array}{l}676(\mathrm{~m}) 643 \\
(\mathrm{~m}) 629(\mathrm{~m})\end{array}$ & $\begin{array}{l}687(\mathrm{w}) 661 \\
(\mathrm{~m}) 622(\mathrm{~m})\end{array}$ & $\begin{array}{c}631(\mathrm{~m}) 599 \\
(\mathrm{w})\end{array}$ & $620(\mathrm{~m} \mathrm{~b})$ & $\begin{array}{c}634(\mathrm{~m}) 603 \\
(\mathrm{w})\end{array}$ & $655(\mathrm{~m})$ & $\begin{array}{c}648(\mathrm{w}) 626 \\
(\mathrm{~m})\end{array}$ \\
\hline$v(\mathrm{Ti}-\mathrm{O})\left(\mu_{3}-\mathrm{O}\right)$ & $\begin{array}{c}575(\mathrm{w}) 545 \\
\quad(\mathrm{vw})\end{array}$ & $\begin{array}{c}588(w) 564 \\
(w)\end{array}$ & $\begin{array}{c}599(\mathrm{w}) 562 \\
(\mathrm{w}) 544(\mathrm{~m}) \\
529(\mathrm{~m})\end{array}$ & $528(w)$ & $\begin{array}{l}605(\mathrm{~m} \mathrm{~b}) 545 \\
(\mathrm{vw}) 529(\mathrm{w})\end{array}$ & $535(\mathrm{vw})$ & $\begin{array}{c}545(\mathrm{w}) 528 \\
(\mathrm{~m})\end{array}$ & $532(w)$ \\
\hline$v(\mathrm{Ti}-\mathrm{O})\left(\mu_{3}-\mathrm{O}\right)$ & $457(\mathrm{w}) 440(\mathrm{w})$ & $\begin{array}{c}474(w) 448 \\
(w)\end{array}$ & $486476(\mathrm{w}$ b) & $450440(w$ b) & $\begin{array}{c}477462(\mathrm{w} b) \\
440\end{array}$ & $431(w b)$ & $\begin{array}{c}478(\mathrm{~m} \mathrm{~b}) \\
(\mathrm{w})\end{array}$ & $\begin{array}{l}458(\mathrm{w}) 426 \\
(\mathrm{~m})\end{array}$ \\
\hline & $419(w)$ & $415(\mathrm{~m})$ & $416(\mathrm{vw})$ & $415(w)$ & & $415(w)$ & & $415(w)$ \\
\hline $\begin{array}{c}\delta(\mathrm{OTiO}) \\
(\mathrm{OR}) v(\mathrm{Ti}-\mathrm{O}) \\
\left(\mu_{3}-\mathrm{O}\right)\end{array}$ & - & $\begin{array}{l}358(w) \\
342(w)\end{array}$ & - & $332(\mathrm{~m} \mathrm{~b})$ & - & $345332(\mathrm{~m} \mathrm{~b})$ & - & $332(\mathrm{~m} \mathrm{~b})$ \\
\hline
\end{tabular}




\section{IR spectrum}

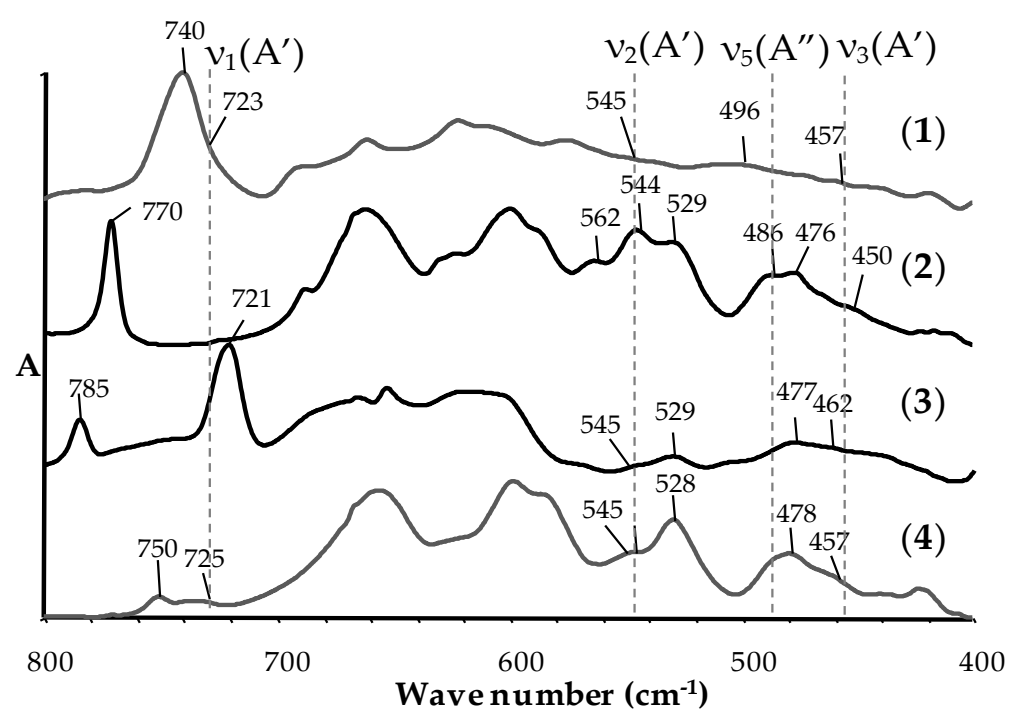

(a)

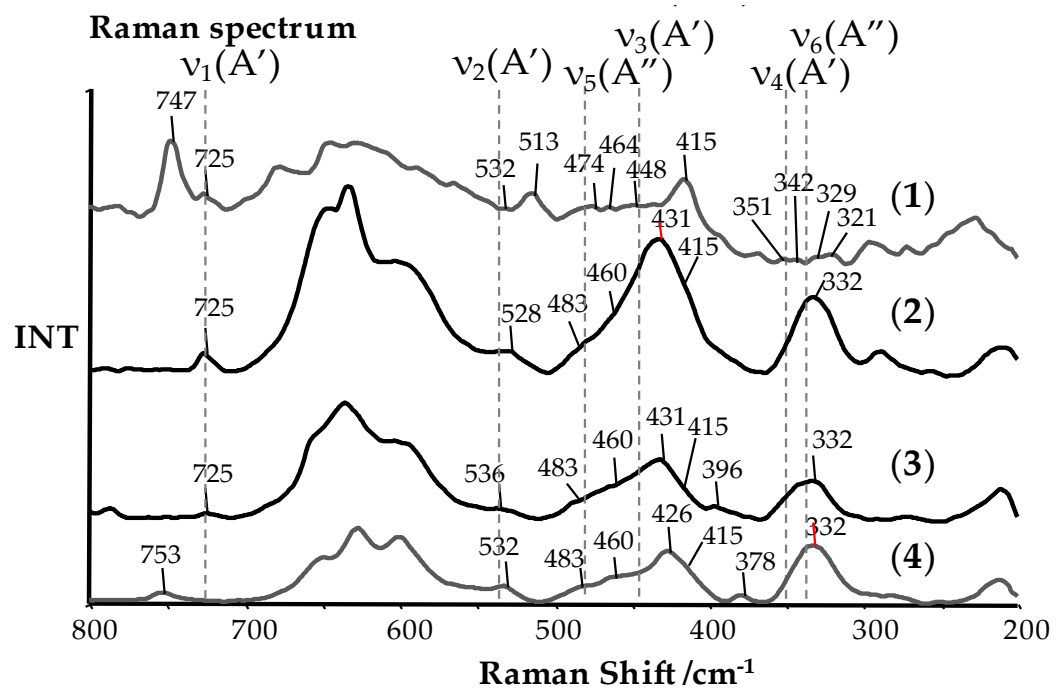

(b)

Figure 2. IR (a) and Raman (b) spectra of (1-4) complexes, registered in the range of appearance of bands coming from vibrations of $\left\{\mathrm{Ti}_{3} \mathrm{O}\right\}$ bridges.

\subsection{UV-Vis Absorption Spectra, Band Gap Determination and DOS Plots}

The optical band gaps of studied complexes were determined using the diffuse reflectance spectroscopy (UV-Vis-DRS). According to this method, the band gap values have been designated on the basis on the extrapolation of the linear part of Kubelka-Munk (K-M) function versus light energy, i.e. $K=f(h v)\left(K=(1-R)^{2} / 2 R, R\right.$ is reflectance) [32,33]. Results of these studies are presented in Figure 3 and Table 5. 

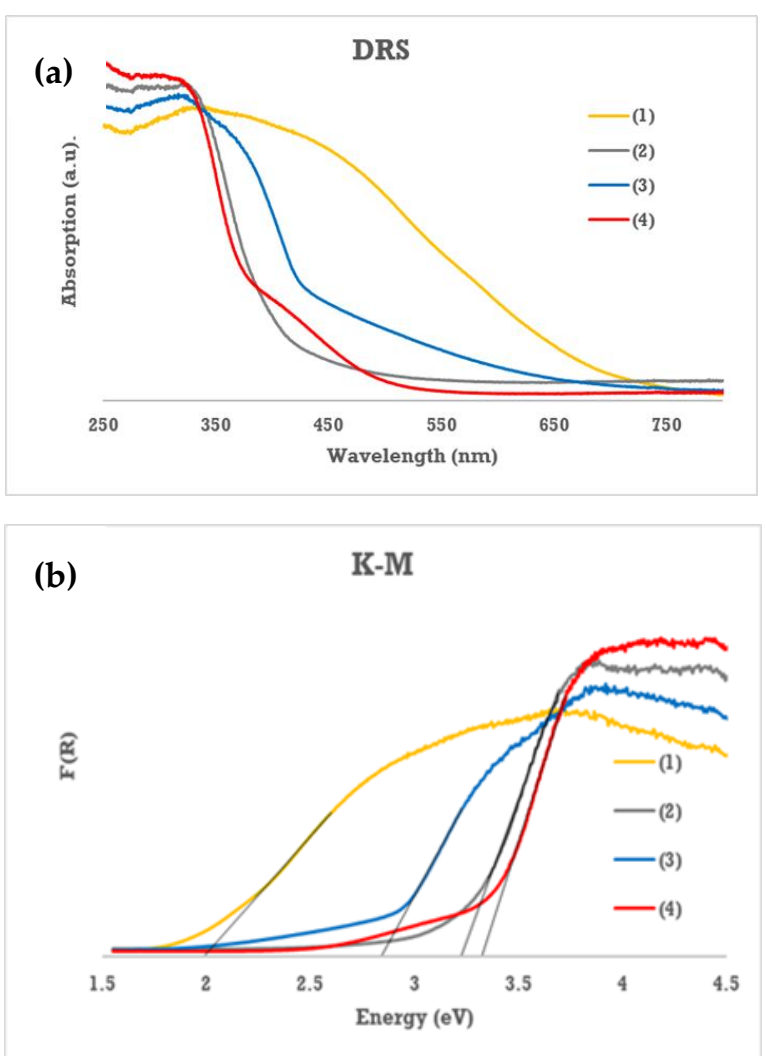

Figure 3. UV-Vis-DRS spectra of (1-4) complexes (a) and Kubelka-Munk function versus light energy plot for the band gap determination $(\mathbf{b})$.

According to this data, compounds (2) and (4) absorption threshold is localized in the UV region of the DRS spectrum and is supported by optically determined band gaps of 3.23 and $3.33 \mathrm{eV}$ respectively. While, in the case of (3) and (1) complexes these thresholds are shifted towards the Visible part of this spectrum. Corresponding band gaps of these complexes were evaluated as 2.84 and $1.99 \mathrm{eV}$ for (3) and (1), respectively. The experimentally determined band gap values have been supported by DFT calculations of modeled molecules of (1-4) clusters (Figure 4 and Table 5). In carried out calculations, the - $\mathrm{O}^{\mathrm{i} P r}$ ligands have been exchanged on -OMe groups for simplicity. According to data listed in Table 5 we observed the clear differences of the energy gap values determined using experimental and theoretical methods, however this agrees with the tendency of hybrid density functionals to overestimate predicted HOMO-LUMO gaps [34].

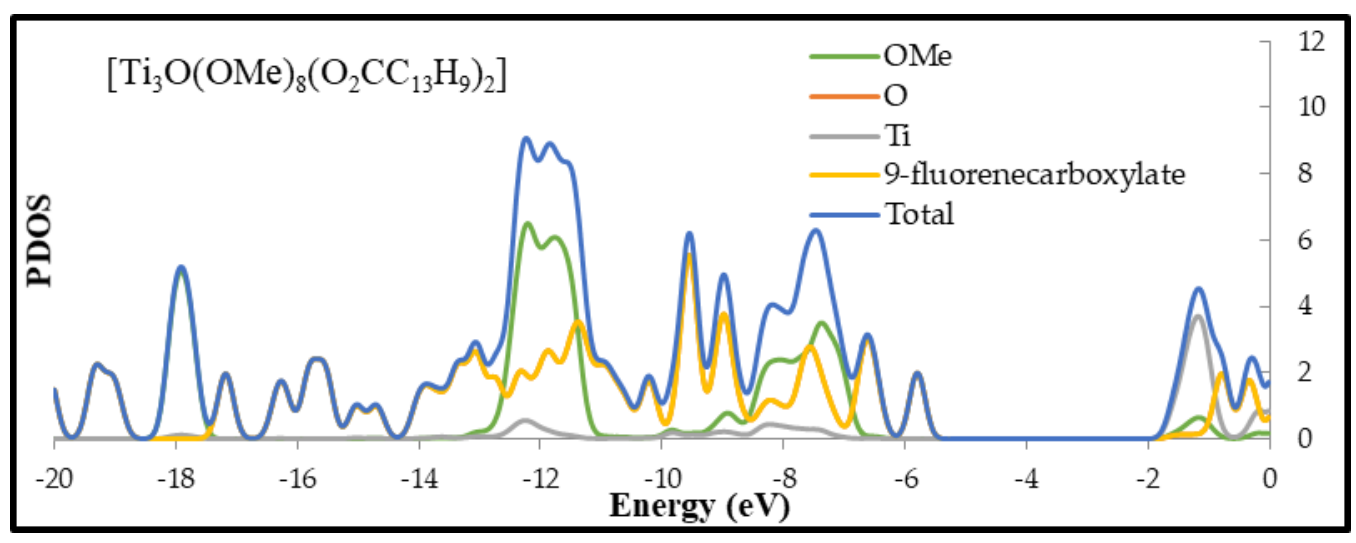

Figure 4. Cont. 

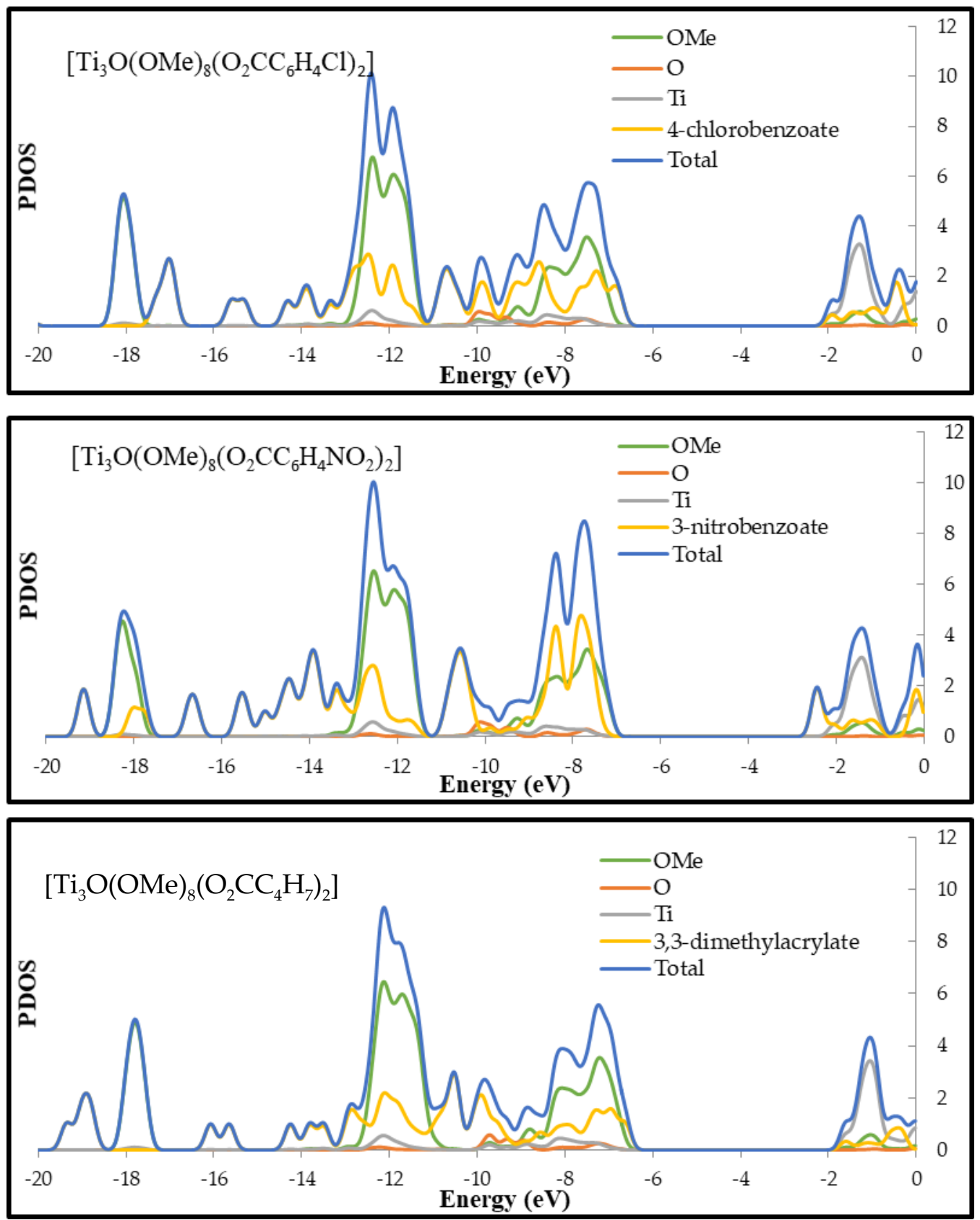

Figure 4. Plots calculated with B3LYP/6-31G(d) level of theory for optimized geometries of $\left[\mathrm{Ti}_{3} \mathrm{O}(\mathrm{OMe})_{8}\left(\mathrm{O}_{2} \mathrm{CC}_{13} \mathrm{H}_{9}\right)_{2}\right],\left[\mathrm{Ti}_{3} \mathrm{O}(\mathrm{OMe})_{8}\left(\mathrm{O}_{2} \mathrm{CC}_{6} \mathrm{H}_{4}-\mathrm{Cl}\right)_{2}\right],\left[\mathrm{Ti}_{3} \mathrm{O}(\mathrm{OMe})_{8}\left(\mathrm{O}_{2} \mathrm{CC}_{6} \mathrm{H}_{4}-\mathrm{NO}_{2}\right)_{2}\right]$, and $\left[\mathrm{Ti}_{3} \mathrm{O}(\mathrm{OMe})_{8}\left(\mathrm{O}_{2} \mathrm{CC}_{4} \mathrm{H}_{7}\right)_{2}\right]$ clusters.

Table 5. Determined experimentally (DRS) band gaps and theoretically calculated HOMO-LUMO separation gaps (B3LYP/6-31G(d) level of theory). In calculations the $\mathrm{O}^{\mathrm{i}} \mathrm{Pr}$ ligands were exchanged with OMe groups.

\begin{tabular}{cccc}
\hline Complex & $\begin{array}{c}\text { Calculated } \\
\text { HOMO-LUMO } \\
\text { Separation Gap [eV] }\end{array}$ & & Experimental Band Gap [eV] \\
\hline$\left[\mathrm{Ti}_{3} \mathrm{O}(\mathrm{OMe})_{8}\left(\mathrm{O}_{2} \mathrm{CC}_{13} \mathrm{H}_{9}\right)_{2}\right]$ & 3.75 & {$\left[\mathrm{Ti}_{3} \mathrm{O}\left(\mathrm{O}^{\mathrm{i} P r}\right)_{8}\left(\mathrm{O}_{2} \mathrm{CC}_{13} \mathrm{H}_{9}\right)_{2}\right](\mathbf{1})$} & 1.99 \\
{$\left[\mathrm{Ti}_{3} \mathrm{O}(\mathrm{OMe})_{8}\left(\mathrm{O}_{2} \mathrm{CC}_{6} \mathrm{H}_{4} \mathrm{Cl}\right)_{2}\right]$} & 4.24 & {$\left[\mathrm{Ti}_{3} \mathrm{O}\left(\mathrm{O}^{\mathrm{i} P r}\right)_{8}\left(\mathrm{O}_{2} \mathrm{CC}_{6} \mathrm{H}_{4} \mathrm{Cl}\right)_{2}\right](2)$} & 3.23 \\
{$\left[\mathrm{Ti}_{3} \mathrm{O}(\mathrm{OMe})_{8}\left(\mathrm{O}_{2} \mathrm{CC}_{6} \mathrm{H}_{4} \mathrm{NO}_{2}\right)_{2}\right]$} & 4.20 & {$\left[\mathrm{Ti}_{3} \mathrm{O}\left(\mathrm{O}^{\mathrm{i} P r}\right)_{8}\left(\mathrm{O}_{2} \mathrm{CC}_{6} \mathrm{H}_{4} \mathrm{NO}_{2}\right)_{2}(\mathbf{3})\right.$} & 2.84 \\
{$\left[\mathrm{Ti}_{3} \mathrm{O}(\mathrm{OMe})_{8}\left(\mathrm{O}_{2} \mathrm{CC}_{4} \mathrm{H}_{7}\right)_{2}\right]$} & 4.25 & {$\left[\mathrm{Ti}_{3} \mathrm{O}\left(\mathrm{O}^{\mathrm{i} P r}\right)_{8}\left(\mathrm{O}_{2} \mathrm{CC}_{4} \mathrm{H}_{7}\right)_{2}\right](4)$} & 3.33 \\
\hline
\end{tabular}


Analysis of DFT calculation data presented in Table 5 proved the clear dependence between the band gap value and the type of carboxylate group, which stabilizes the $\left\{\mathrm{Ti}_{3} \mathrm{O}\right\}$ core. The trend of these changes is in good agreement with experimental data.

\subsection{Estimation of Photocatalytic Activity of Trinuclear Ti(IV) Oxo-Complexes}

The photocatalytic activity estimations were carried our using polymer/TOCs composite foils produced by the dispersion of TOCs (1-3) in the polymer solution (poly(methyl methacrylate) (PMMA)) and slow evaporation of the solvent. Scanning electron microscopy (SEM) confirmed the presence of uniformly dispersed microcrystalline powders of studied oxo-complexes in the composite films of 25-50- $\mu \mathrm{m}$ thick (Figure 5).
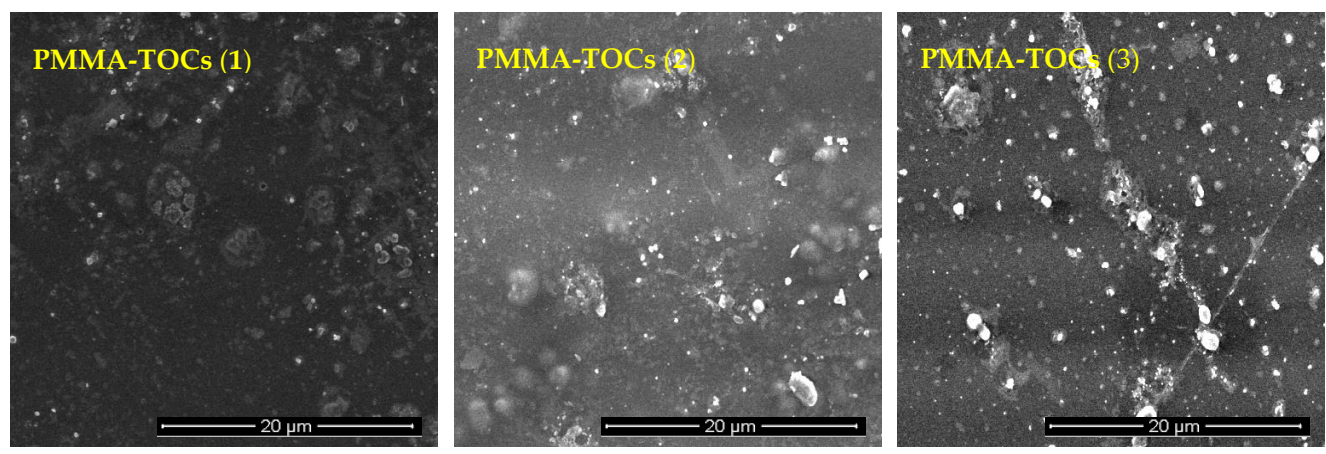

Figure 5. Scanning electron microscopy (SEM) images of PMMA/TOCs composite foils (PMMA = poly(methyl methacrylate); TOCs = (1), (2), (3)) used in photocatalytic experiments.

The photocatalytic activity of synthesized trinuclear Ti(IV) oxo-complexes have been estimated basing on the UV photoinduced degradation process of methylene blue (MB), which is widely used as a standard [35-40]. Hydrophobic properties of studied compounds caused that photocatalytic experiments were carried out using the polymer/TOCs composites produced by TOCs (1-3) microcrystals dispersion in the PMMA matrix. As a blind test a pure PMMA foil without any addition was used. The absorption measurements (at wavelength $664 \mathrm{~nm}$ ) were expressed as methylene blue concentration versus the irradiation time, prior a rate constant calculations. Results of the measurements and pseudo-first order fitting of the methylene blue photocatalysis are presented in Figures 6 and 7, respectively. Apparent rate constants of photodegradation kinetics and decolorization percentage at the end of measurements are presented in Table 6 .

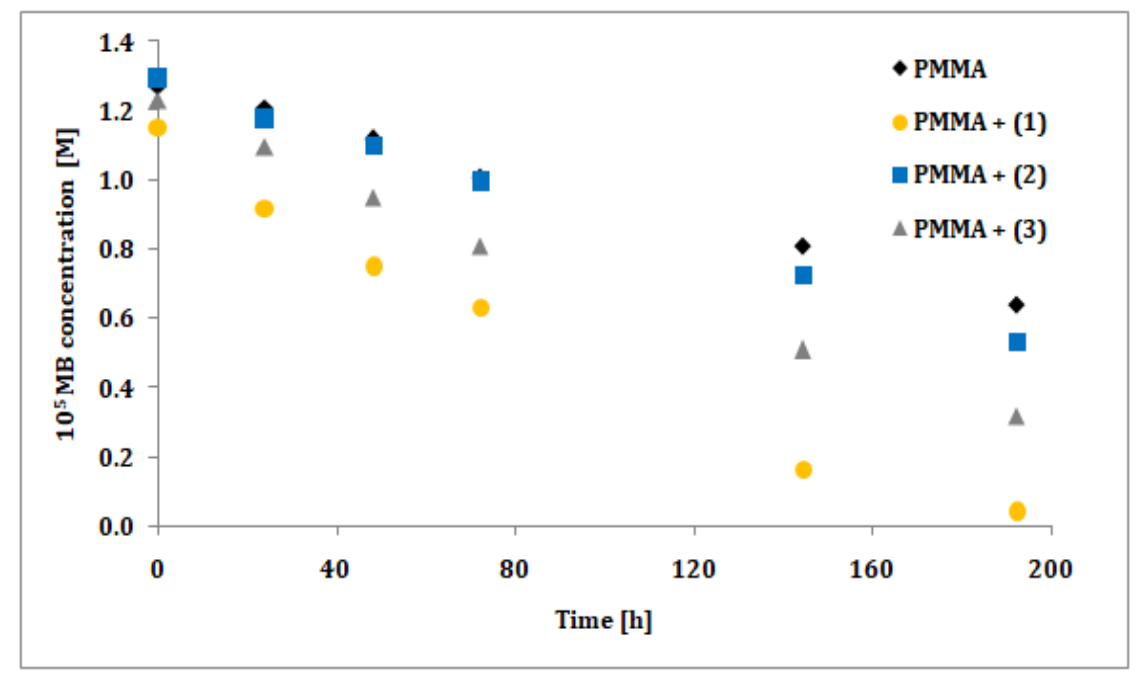

Figure 6. Changes in the concentration of methylene blue (MB) solution under photocatalysis experiment conditions for studied $\mathrm{PMMA} /\left\{\mathrm{Ti}_{3} \mathrm{O}\right\}(1-3)$ composite foils. 


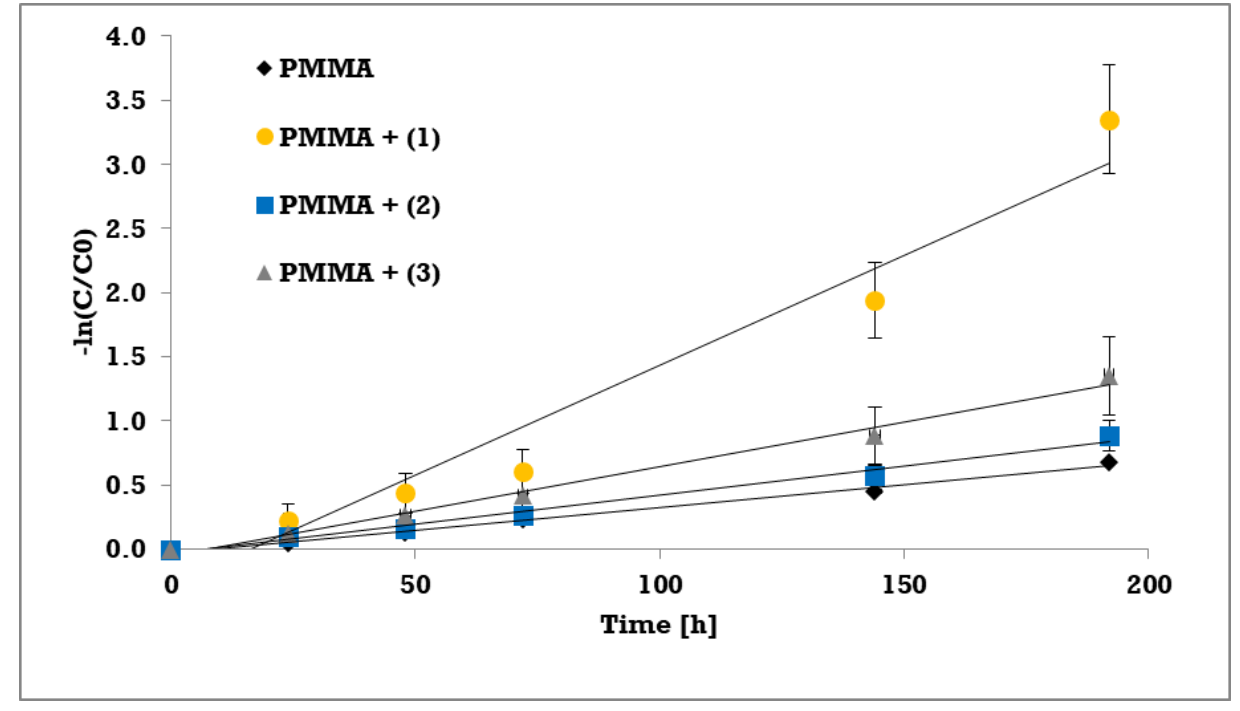

Figure 7. Pseudo-first order fitting of the methylene blue photocatalysis on PMMA foils with selected complexes.

Table 6. Rate constants of MB photodegradation on studied materials and MB decolorization percentage.

\begin{tabular}{|c|c|c|c|}
\hline Sample & MB Decolorization ${ }^{a}[\%]$ & $10^{2}$ Rate Constant, $\left[\mathrm{h}^{-1}\right]$ & $\mathbf{R}^{2}$ \\
\hline PMMA & 49 & $0.35 \pm 0.02$ & 0.991 \\
\hline PMMA + (1) & 96 & $1.72 \pm 0.19$ & 0.953 \\
\hline PMMA + (2) & 59 & $0.45 \pm 0.03$ & 0.987 \\
\hline PMMA + (3) & 74 & $0.70 \pm 0.03$ & 0.990 \\
\hline
\end{tabular}

${ }^{\text {a }}$ MB decolorization at the end of measurements $(t=192 \mathrm{~h})$.

\section{Discussion}

The single crystal X-ray diffraction studies of (2) and (3) allowed to solve their structures as the $\left[\mathrm{Ti}_{3} \mathrm{O}\left(\mathrm{O}^{\mathrm{i}} \mathrm{Pr}\right)_{8}\left(\mathrm{O}_{2} \mathrm{CR}^{\prime}\right)_{2}\right]\left(\mathrm{R}^{\prime}=-p-\mathrm{PhCl}\right.$ and $\left.-m-\mathrm{PhNO}_{2}\right)$ clusters. The compounds, which contain a similar type of the titanium-oxo core were also synthesized in the reaction of $\mathrm{Ti}_{3} \mathrm{O}\left(\mathrm{O}^{\mathrm{i}} \mathrm{Pr}\right)_{10}$ and $\mathrm{Ti}_{3} \mathrm{O}\left(\mathrm{O}^{\mathrm{i}} \mathrm{Pr}\right)_{9}(\mathrm{OMe})$ with benzoic acid at $\mathrm{RT}$ in toluene as the solvent [14], and 1:1 reaction of $\left[\mathrm{Ti}\left(\mathrm{OCH}_{2} \mathrm{Me}_{3}\right)_{4}\right]_{2}$ with such organic acids as $\mathrm{HO}_{2} \mathrm{CH}, \mathrm{HO}_{2} \mathrm{CMe}$, and $\mathrm{HO}_{2} \mathrm{CH}_{2} \mathrm{CMe}_{3}$ in toluene [13]. In an environment of the organic acid excess, oxo-complexes of the general formula $\left[\mathrm{Ti}_{3} \mathrm{O}\left(\mathrm{O}^{\mathrm{i}} \mathrm{Pr}\right)_{6}\left(\mathrm{O}_{2} \mathrm{C} \text {-adamantyl }\right)_{4}\right]$ (1:1.8, in THF) and $\left[\mathrm{Ti}_{3} \mathrm{O}_{2}\left(\mathrm{O}^{\mathrm{i}} \mathrm{Pr}\right)_{3}\left(\mathrm{O}_{2} \mathrm{CCF}_{3}\right)_{5}\right]\left(1: 2\right.$, in ${ }^{\mathrm{i}} \mathrm{PrOH}$ and $\mathrm{CH}_{3} \mathrm{COOH}$ mixture), can be formed [15]. Contrary to earlier reports oxo-complexes (2) and (3) were synthesized in the direct reaction of titanium (IV) isopropoxide with 4-chlorobenzoic acid and 3-nitrobenzoic acid, respectively in 4:1 molar ratio at RT in inert atmosphere, using 1:1 THF/ $\mathrm{PrOH}$ mixture as a solvent. In these conditions were also isolated crystalline powders of (1) (9-fluorenecarboxylic acid) and (4) (3,3 dimethylacrylic acid), which structures were determined on the basis of IR and Raman spectroscopy.

Analysing the structural data of (2) and (3), drew attention to the clear impact of the carboxylate group type on the geometry of the $\left\{\mathrm{Ti}_{3} \mathrm{O}\right\}$ bridge, especially on the oxygen atom distance versus plane formed by three titanium atoms. In the case of $(2)(-p-\mathrm{PhCl})$ this distance is larger than for $(3)\left(-m-\mathrm{PhNO}_{2}\right)$ and being $0.36 \AA$ and $0.24 \AA$, respectively. A similar effect was also noticed for $\left[\mathrm{Ti}_{4} \mathrm{O}_{2}\left(\mathrm{O}^{\mathrm{i} B u}\right)_{10}\left(\mathrm{O}_{2} \mathrm{CR}^{\prime}\right)_{2}\right]$ $\left(\mathrm{R}^{\prime}=-\mathrm{C}_{13} \mathrm{H}_{9},-m-\mathrm{PhCl},-m-\mathrm{PhNO}_{2},-p-\mathrm{PhNH}_{2}\right)$ complexes [12]. Due to the weak quality of isolated crystals of (1) and (4), their structure has been determined basing vibrational spectra (IR and Raman) analysis. Bands, which were found at $1400-1700 \mathrm{~cm}^{-1}$ and $900-1050 \mathrm{~cm}^{-1}$ proved the presence of coordinated carboxylate and alkoxide groups (Table 4). Moreover between 1400 and $1700 \mathrm{~cm}^{-1}$, the presence of bands derived from $v\left(\mathrm{NO}_{2}\right)(4)$ and $v(\mathrm{C}=\mathrm{C})((\mathbf{1}),(3))$ was noticed. This fact confirms the coordination of the relevant carboxylate groups in structures of all investigated oxo-clusters. The 
splitting of $v\left(\right.$ Ti-OR) bands (in the range $900-1050 \mathrm{~cm}^{-1}$ ) indicated on the presence of two differently coordinated alkoxide ligands types, i.e. bridging and terminal ones. This is consistent with the structural data of (2) and (3), which show that $\left\{\mathrm{Ti}_{3} \mathrm{O}\right\}$ core is stabilized by two alkoxide bridges (Figure 1 , Table 2). However, the basis of the $\left\{\mathrm{Ti}_{3} \mathrm{O}\right\}$ core identification was the presence of medium or weak bands in IR and Raman spectra of (1-4) clusters, which can be attributed to the normal vibrations of $\mathrm{Ti}_{3}-\left(\mu_{3}-\mathrm{O}\right)$ bridges (Figure 1). Analysis of data presented in Table 2 indicates that this type of bridge forms a trigonal pyramid belonging to the Cs point group [41], where the oxygen atom forms two Ti-O bonds with the similar lengths and one slightly longer bond. This type of oscillator is represented by six normal vibrations, which are active both the IR and Raman spectra. The use of DFT method allowed on the frequency calculation of normal vibrations for the reference system $\left[\mathrm{Ti}_{3} \mathrm{O}(\mathrm{OMe})_{8}\left(\mathrm{O}_{2} \mathrm{Me}\right)_{2}\right]$ and clusters containing studied carboxylate groups (Table 3). Obtained results revealed that the bands derived from stretching and bending vibrations of $\mathrm{Ti}_{3}-\left(\mu_{3}-\mathrm{O}\right)$ bridges should appear at $480-750 \mathrm{~cm}^{-1}$ and $340-450 \mathrm{~cm}^{-1}$, respectively. The presence of weak/middle bands in above mentioned IR and Raman spectra regions of synthesized (1-4) compounds may be evidence that the structure of these compounds consists of $\left\{\mathrm{Ti}_{3} \mathrm{O}\right\}$ cores (Figure 2).

The optical properties of (1-4) oxo-complexes in a broad range of absorption, i.e. between $350 \mathrm{~nm}$ and $750 \mathrm{~nm}$, were confirmed by analysis of their UV-Vis-DRS spectra (Table 5). The values of energy gaps change from $1.99 \mathrm{eV}\left(-\mathrm{O}_{2} \mathrm{CC}_{13} \mathrm{H}_{9}(\mathbf{1})\right)$ up to $3.23-3.33 \mathrm{eV}\left(-\mathrm{O}_{2} \mathrm{C}-\mathrm{p}-\mathrm{PhCl}(\mathbf{2})\right.$ and $-\mathrm{O}_{2} \mathrm{CC}_{4} \mathrm{H}_{7}$ (4)) dependently to the type of the carboxylate group. It should be noted that above mentioned band gaps determined for trinuclear oxo-complexes are clearly lower compared to those, which were found for $\left[\mathrm{Ti}_{4} \mathrm{O}_{2}\left(\mathrm{O}^{\mathrm{i}} \mathrm{Bu}\right)_{10}\left(\mathrm{O}_{2} \mathrm{CR}^{\prime}\right)_{2}\right]\left(\mathrm{R}^{\prime}=-\mathrm{C}_{13} \mathrm{H}_{9},-m-\mathrm{PhCl},-m-\mathrm{PhNO}_{2},-p-\mathrm{PhNH}_{2}\right)$ that ranged between $2.55 \mathrm{eV}\left(-\mathrm{O}_{2} \mathrm{CC}_{13} \mathrm{H}_{9}\right)$ and $3.59 \mathrm{eV}\left(-\mathrm{O}_{2} \mathrm{C}-m-\mathrm{PhCl}\right)$ [12]. The comparison of the band gap determined for trinuclear and tetranuclear clusters exhibited the clear decrease of the band gap energy for oxo-complexes containing fluorenecarboxylate $\left(-\mathrm{O}_{2} \mathrm{CC}_{13} \mathrm{H}_{9}\right)$ and $m$-nitrobenzoate $\left(-\mathrm{O}_{2} \mathrm{C}-m\right.$ - $\left.\mathrm{PhNO}_{2}\right)$ groups. Moreover, the obtained results showed that the band gap of $\mathrm{Ti}(\mathrm{IV})$ oxo-complexes containing $-\mathrm{O}_{2} \mathrm{CPhCl}$ groups decrease up to $3.23 \mathrm{eV}-3.59 \mathrm{eV}$ independently to the location of the $-\mathrm{Cl}$ substituent in the benzene ring. The lower band gap values of trinuclear oxo-complexes in comparison to the analogous tetranuclear $\mathrm{Ti}_{4} \mathrm{O}_{2}\left(\mathrm{O}^{\mathrm{i}} \mathrm{Bu}\right)_{10}\left(\mathrm{O}_{2} \mathrm{CR}^{\prime}\right)_{2}$ complexes may be explained on the basis of structural features and performed DFT calculations. The main factor that sets apart both systems is the presence of five-fold coordinated titanium atom in the structure of trinuclear oxo-complexes, representing slightly disordered trigonal bipyramidal coordination geometry. As it was shown by DFT results, in case of (1), (2), and (4) this particular titanium atom's d-orbitals hold the highest electronic density of LUMO, which may be reflected in narrowing of the band gap. Similar effect is observed in the case of anatase $\mathrm{TiO}_{2}$ crystals with different facets exposed. Crystals dominant with 5 coordinated titanium atoms, i.e. $\{001\}$ facet exhibit lower bandgap compared to crystals with dominant $\{101\}$ facet composed of roughly 50\% 6-coordinated Ti and 50\% 5-coordinated Ti [42]. For discrete structures like presented trinuclear oxo-complex this may have a significant role in the band gap characteristic.

DFT calculations were also carried out in order to determine of the electronic structure of (1-4) oxo-complexes. Partial density of states (PDOS) plots and calculated highest-occupied molecular orbital (HOMO) and lowest-occupied molecular orbital (LUMO) of studies clusters are presented in Figure 4 and Figure S3 respectively. In the case of (1), (2), and (4) complexes HOMO orbitals are located on corresponding ligands. Main contributors to electron density of these orbitals are $\pi$ orbitals (phenyl rings for (1) and (2) and $\mathrm{C}=\mathrm{C}$ bond for (4)) and carbonyl group oxygen of carboxylate ligand (Figure S3). For (2) and (4), the HOMO orbitals are close to the orbitals of the core, which are mainly composed of core and alkoxides oxygen orbitals, while $(\mathbf{1})\left(-\mathrm{O}_{2} \mathrm{CC}_{13} \mathrm{H}_{9}\right)$ shows structure characterized by deep penetration of the oxo-titanium core energy gap by ligand orbital (see PDOS plot). The electronic density of LUMO for (1), (2), and (4) is located on titanium atoms of the core. LUMO of (2) and (4) shows a little contribution of the ligand's orbitals, while the LUMO of (1) is almost solely composed of $3 \mathrm{~d}$ Ti orbitals of the core. These results indicate that the HOMO-LUMO transition for (1), (2) and (4) involves ligand-to-core charge transfer (LCCT). Compounds (1), (2) and (4) can be described as n-type 
doped semiconductors in regard to the unfunctionalized cluster. The situation is different in case of compound (3) where HOMO is located on oxygen atoms of the core and LUMO is composed purely of $\mathrm{m}$-nitrobenzoate ligand, mainly on $-\mathrm{NO}_{2}$ group. This complex may be described as $p$-type doped semiconductor with reference to unfunctionalized cluster.

The photocatalytic activity of studied compounds were estimated by methylene blue (MB) UV photoinduced degradation on the surface of composite PMMA foils enriched with TOCs ((1-3)). Obtained data was processed in terms of MB decolorization percentage after $192 \mathrm{~h}$ of experiment, and apparent pseudo-first order rate constant for methylene blue decomposition (Table 6). According to this data, the lowest activity exhibited the PMMA/TOCs (2) system, which photocatalytic activity is only slightly different of the reference sample, i.e. pure PMMA foil. Two times faster decomposition was noticed for PMMA/TOCs (3), but the most photocatalytic active sample was PMMA/TOCs (1) that elevates photodegradation rate fivefold. The decolorization percentage [24] after $192 \mathrm{~h}$ of UV irradiation follows the same trend as kinetic rate constants and changing in the row (1) $96 \%>$ (3) $74 \%$ > (2) $59 \%$ (to reference sample it was $49 \%$ ). It should be noted that the above-mentioned results change in accordance with the growing values of energy band gaps. Obtained results of photocatalytic activity have been compared to previously studied PMMA-TOCs systems, which contain tetranuclear TOCs with the same carboxylate groups $\left(\left[\mathrm{Ti}_{4} \mathrm{O}_{2}\left(\mathrm{O}^{\mathrm{i}} \mathrm{Bu}\right)_{10}\left(\mathrm{O}_{2} \mathrm{CR}^{\prime}\right)_{2}\right] ; \mathrm{R}^{\prime}=-\mathrm{C}_{13} \mathrm{H}_{9}\right.$ and $\left.-m-\mathrm{PhNO}_{2}\right)$ [12]. For the sake of comparison, the rate constants of MB photodegradation on the surface of PMMA-TOCs $\left(\left\{\mathrm{Ti}_{4} \mathrm{O}_{2}\right\}\right)$ systems were calculated with the same approach as in current study (Table 7).

Table 7. Comparison of MB photodegradation rate constants for $\left\{\mathrm{Ti}_{3} \mathrm{O}\right\}$ and $\left\{\mathrm{Ti}_{4} \mathrm{O}_{2}\right\}$ with the same carboxylate ligands (for tetranuclear Ti (IV) oxo-complexes, rate constant were calculated in accordance with the procedure used in this paper).

\begin{tabular}{cccc}
\hline TOCs & $\left\{\mathbf{T i}_{\mathbf{a}} \mathbf{O}_{\mathbf{b}}\right\}$ Core & $\mathbf{1 0}^{\mathbf{2}}$ Rate Constant $\left.\mathbf{h}^{\mathbf{- 1}}\right]$ & $\mathbf{R}^{\mathbf{2}}$ \\
\hline$\left[\mathrm{Ti}_{3} \mathrm{O}\left(\mathrm{O}^{\mathrm{i} P r}\right)_{8}\left(\mathrm{O}_{2} \mathrm{CC}_{13} \mathrm{H}_{9}\right)_{2}\right]$ & $\left\{\mathrm{Ti}_{3} \mathrm{O}\right\}$ & $1.72 \pm 0.19$ & 0.953 \\
{$\left[\mathrm{Ti}_{4} \mathrm{O}_{2}\left(\mathrm{O}^{\mathrm{i}} \mathrm{Bu}\right)_{10}\left(\mathrm{O}_{2} \mathrm{CC}_{13} \mathrm{H}_{9}\right)_{2}\right]$} & $\left\{\mathrm{Ti}_{4} \mathrm{O}_{2}\right\}$ & $1.45 \pm 0.11$ & 0.973 \\
{$\left[\mathrm{Ti}_{3} \mathrm{O}\left(\mathrm{O}^{\mathrm{i} P r}\right)_{8}\left(\mathrm{O}_{2} \mathrm{C}-m-\mathrm{PhNO}_{2}\right)_{2}\right]$} & $\left\{\mathrm{Ti}_{3} \mathrm{O}\right\}$ & $0.70 \pm 0.03$ & 0.990 \\
{$\left[\mathrm{Ti}_{4} \mathrm{O}_{2}\left(\mathrm{O}^{\mathrm{i} B u}\right)_{10}\left(\mathrm{O}_{2} \mathrm{C}-m-\mathrm{PhNO}_{2}\right)_{2}\right]$} & $\left\{\mathrm{Ti}_{4} \mathrm{O}_{2}\right\}$ & $0.47 \pm 0.03$ & 0.977 \\
\hline
\end{tabular}

Analysis of this data revealed that trinuclear Ti(IV) species exhibit better photocatalytic response than tetranuclear Ti(IV) ones with the same carboxylate ligands. Similar to the band gap dependencies, the unsaturated Ti atom may play a paramount role in facilitating the photocatalytic response. In case of $\mathrm{TiO}_{2}$, it has been shown that the increased percentage area of $\{001\}$ facets, rich in fivefold coordinated Ti atoms, is beneficial for both organic contaminations molecules adsorption and retarding charge recombination [42].

\section{Conclusions}

Trinuclear Ti(IV) oxo-complexes [ $\left.\mathrm{Ti}_{3} \mathrm{O}\left(\mathrm{O}^{\mathrm{i}} \mathrm{Pr}\right)_{8}\left(\mathrm{O}_{2} \mathrm{CR}^{\prime}\right)_{2}\right]\left(\mathrm{R}^{\prime}=-\mathrm{C}_{13} \mathrm{H}_{9}(\mathbf{1}),-p-\mathrm{PhCl}(\mathbf{2}),-m-\mathrm{PhNO}_{2}\right.$ (3), $\left.-\mathrm{C}_{4} \mathrm{H}_{7}(4)\right)$ were isolated as a result of the direct reaction of titanium(IV) isopropoxide with the respective organic acids using 4:1 molar ratio $\left(\mathrm{Ti}\left(\mathrm{O}^{\mathrm{i}} \mathrm{Pr}\right)_{4} / \mathrm{HOOCR}^{\prime}\right)$ and 1:1 mixture of THF/i $\mathrm{PrOH}$ as a solvent. The single crystals $\mathrm{X}$-ray diffraction studies proved the formation of trinuclear Ti(IV) oxo-complexes (2) and (3), while the trinuclear structures of (1) and (4) (due to the poor quality of the crystals) have been identified basis the analysis of their IR and Raman spectra.

According to diffuse reflectance spectra, the introduction of 9-fluorenecarboxylate ligands into the trinuclear Ti(IV) oxo-complex (1) significantly extend the visible absorption range and reduce the band gap in comparison to compounds (2) and (4), i.e. substituted by 4-chlorobenzoic carboxylate and 3,3-dimethylacrylic carboxylate ligands. In the case of compound (3), containing 3-nitrobenzoic carboxylate groups, above mentioned effect is clearly lower than for (1).

The results of photocatalytic experiments revealed that activity of synthesized trinuclear oxo-complexes change in the order $(\mathbf{1})>(3)>(2)$. Photocatalytic activity studies of PMMA/TOCs 
composites $\left(\mathrm{TOCs}=\left[\mathrm{Ti}_{3} \mathrm{O}\left(\mathrm{O}^{\mathrm{i}} \mathrm{Pr}\right)_{8}\left(\mathrm{O}_{2} \mathrm{CR}^{\prime}\right)_{2}\right]\right.$ and $\left.\left[\mathrm{Ti}_{4} \mathrm{O}_{2}\left(\mathrm{O}^{\mathrm{i}} \mathrm{Bu}\right)_{10}\left(\mathrm{O}_{2} \mathrm{CR}^{\prime}\right)_{2}\right], \mathrm{R}^{\prime}=-\mathrm{C}_{13} \mathrm{O}_{9},-m-\mathrm{PhNO}_{2}\right)$ shows clearly that trinuclear $\mathrm{Ti}(\mathrm{IV})$ oxo-complexes exhibit the better photocatalytic activity than tetranuclear ones. It suggests that polymer coatings enriched with trinuclear Ti(IV) oxo-complex grains should reveal the appropriate properties as the system, which may be used for photodegradation of the biological/organic pollution.

Supplementary Materials: The following are available online at http:/www.mdpi.com/1996-1944/12/19/3195/s1. CCDC 1942884 and 1942885 contain the supplementary crystallographic data for (2), and (3), respectively. This data can be obtained free of charge via http://www.ccdc.cam.ac.uk/conts/retrieving.html, or from the Cambridge Crystallographic Data Centre, 12 Union Road, Cambridge CB2 1EZ, UK; fax: (+44) 1223-336-033; or e-mail: deposit@ccdc.cam.ac.uk. Figure S1: IR spectra of studied trinuclear Ti(IV) oxo-complexes, Figure S2: Raman spectra of studied trinuclear Ti(IV) oxo-complexes, Figure S3: The calculated representation of the HOMO and LUMO orbitals for studied oxo-complexes, Table S1: Atom coordinates for optimized $\left[\mathrm{Ti}_{3} \mathrm{O}(\mathrm{OMe})_{8}\left(\mathrm{O}_{2} \mathrm{CC}_{13} \mathrm{H}_{9}\right)_{2}\right]$ structure, Table S2: Atom coordinates for optimized $\left[\mathrm{Ti}_{3} \mathrm{O}(\mathrm{OMe})_{8}\left(\mathrm{O}_{2} \mathrm{CC}_{6} \mathrm{H}_{4} \mathrm{Cl}\right)_{2}\right]$ structure, Table S3: Atom coordinates for optimized $\left[\mathrm{Ti}_{3} \mathrm{O}(\mathrm{OMe})_{8}\left(\mathrm{O}_{2} \mathrm{CC}_{6} \mathrm{H}_{4} \mathrm{NO}_{2}\right)_{2}\right]$ structure, Table S4: Atom coordinates for optimized $\left[\mathrm{Ti}_{3} \mathrm{O}(\mathrm{OMe})_{8}\left(\mathrm{O}_{2} \mathrm{CC}_{4} \mathrm{H}_{7}\right)_{2}\right]$ structure.

Author Contributions: Conceptualization, P.P. and M.J.; Methodology, M.J., P.P., and T.M.M..; Formal Analysis, P.P., M.J., and T.M.M..; Investigation, M.J., and T.M.M..; Data Curation, P.P., T.M.M., and M.J..; Writing - Original Draft Preparation, P.P.; Writing - Review \& Editing, P.P.; Supervision, P.P.

Funding: This research received no external funding.

Acknowledgments: Diffraction data was collected on BL14.X $(X=[1,2,3])$ at the BESSY II electron storage ring operated by the Helmholtz-Zentrum Berlin [43]. We would particularly like to acknowledge the help and support of Dr. Piotr Wilk during the experiment.

Conflicts of Interest: The authors declare no conflicts of interest. The sponsors had no role in the design, execution, interpretation, or writing of the study.

\section{References}

1. Coppens, P.; Chen, Y.; Trzop, E. Crystallography and Properties of Polyoxotitanate Nanoclusters. Chem. Rev. 2014, 114, 9645-9661. [CrossRef] [PubMed]

2. Rozes, L.; Sanchez, C. Titanium oxo-clusters: Precursors for a Lego-like construction of nanostructured hybrid materials. Chem. Soc. Rev. 2011, 40, 1006-1030. [CrossRef]

3. Nunes, D.; Pimentel, A.; Gonçalves, A.; Pereira, S.; Branquinho, R.; Barquinha, P.; Fortunato, E.; Martins, R. Metal Oxide Nanostructures for Sensor Applications. Semicond. Sci. Technol. 2019, 34, 043001. [CrossRef]

4. Li, N.; Matthews, P.D.; Luo, H.K.; Wright, D.S. Novel properties and potential applications of functional ligand-modified polyoxotitanate cages. Chem. Commun. 2016, 52, 11180-11190. [CrossRef]

5. Fang, W.H.; Zhang, L.; Zhang, J. Synthetic strategies, diverse structures and tunable properties of polyoxo-titanium clusters. Chem. Soc. Rev. 2018, 47, 404-421. [CrossRef] [PubMed]

6. Nguyen, H.L.; Vu, T.T.; Le, D.; Doan, T.L.H.; Nguyen, V.Q.; Phan, N.T.S. A Titanium-Organic Framework: Engineering of the Band-Gap Energy for Photocatalytic Property Enhancement. Acs Catatysis 2017, 7, 338-342. [CrossRef]

7. Scanlon, D.O.; Dunnill, C.W.; Buckeridge, J.; Shevlin, S.A.; Logsdail, A.J.; Woodley, S.M.; Catlow, C.R.A.; Powell, M.J.; Palgrave, R.G.; Parkin, I.P.; et al. Band alignment of rutile and anatase $\mathrm{TiO}_{2}$. Nat. Mater. 2013, 12, 798-801. [CrossRef]

8. Liu, J.X.; Gao, M.Y.; Fang, W.H.; Zhang, L.; Zhang, J. Bandgap Engineering of Titanium-Oxo Clusters: Labile Surface Sites Used for Ligand Substitution and Metal Incorporation. Angew. Chem Int. Ed. 2016, 55, 5160-5165. [CrossRef] [PubMed]

9. Cui, Y.; Zou, G.D.; Li, H.M.; Huang, Y.; Fan, Y. 4-Chlorosalicylate-stabilized titanium-oxo clusters with structures mediated by tetrazole and their photophysical properties. Polyhedron 2019,157, 177-182. [CrossRef]

10. Hu, J.; Zhan, J.; Zhang, G.; Zhang, Q.; Du, L.; Tung, C.H.; Wang, Y. Effects of Substitutional Dopants on the Photoresponse of a Polyoxotitanate Cluster. Inorg. Chem. 2016, 55, 8493-8501. [CrossRef] [PubMed]

11. Janek, M.; Muzioł, T.; Piszczek, P. The structure and photocatalytic activity of the tetranuclear titanium(IV) oxo-complexe with 4-aminobenzoate ligands. Polyhedron 2018, 141, 110-117. [CrossRef] 
12. Janek, M.; Radtke, A.; Muzioł, T.; Jerzykiewicz, M.; Piszczek, P. Tetranuclear Oxo-titanium Clusters with Different Carboxylate Aromatic Ligands: Optical Properties, DFT Calculations, and Polymer Composites Photoactivity. Materials 2018, 11, 1661. [CrossRef] [PubMed]

13. Boyle, T.J.; Tyner, R.P.; Alam, B.L.; Scott, B.L.; Ziller, J.W.; Potter, B.G.J. Implications for the Thin-Film Densification of $\mathrm{TiO}_{2}$ from Carboxylic Acid-Modified Titanium Alkoxides. Syntheses, Characterizations, $X$-ray Structures of $\mathrm{Ti}_{3}\left(\mu_{3}-\mathrm{O}\right)\left(\mathrm{O}_{2} \mathrm{CH}\right)_{2}(\mathrm{ONep})_{8}, \mathrm{Ti}_{3}\left(\mu_{3}-\mathrm{O}\right)\left(\mathrm{O}_{2} \mathrm{CMe}\right)_{2}(\mathrm{ONep})_{8}$, $\mathrm{Ti}_{6}\left(\mu_{3}-\mathrm{O}\right)_{6}\left(\mathrm{O}_{2} \mathrm{CCHMe}\right)_{6}(\mathrm{ONep})_{6}$, [ $\left.\mathrm{Ti}\left(\mu \mathrm{O}_{2} \mathrm{CCMe}_{3}\right)(\mathrm{ONep})_{3}\right]_{2}$, and $\mathrm{Ti}_{3}\left(\mu_{3}-\mathrm{O}\right)\left(\mathrm{O}_{2} \mathrm{CCH}_{2} \mathrm{CMe}_{3}\right)_{2}(\mathrm{ONep})_{8}$ $\left(\mathrm{ONep}=\mathrm{OCH}_{2} \mathrm{CMe}_{3}\right)$. J. A. Chem. Soc. 1999, 121, 12104-12112. [CrossRef]

14. Mijatovic, I.; Kickelbick, G.; Puchberger, M.; Schubert, U. Preservation of the cluster core upon formation of $\mathrm{Ti}_{3} \mathrm{O}\left(\mathrm{OPr}^{\mathrm{i}}\right) 8$ (benzoate $)_{2}$ from $\mathrm{Ti}_{3} \mathrm{O}(\mathrm{OR})_{10}$. New J. Chem. Soc. 2003, 27, 3-5. [CrossRef]

15. Czakler, M.; Schubert, U. Carboxylate-substituted $\mathrm{Ti}(\mathrm{IV})$ oxo clusters with a $\mathrm{Ti}_{3} \mathrm{O}$ core. Inorg. Chim. Acta. 2018, 471, 567-569. [CrossRef]

16. Schubert, U. Chemical modification of titanium alkoxides for sol-gel processing. J. Mater. Chem. 2005, 15, 3701-3715. [CrossRef]

17. CrysAlis RED and CrysAlis CCD; Oxford Diffraction Ltd.: Abingdon, Oxfordshire, England, 2000.

18. Krug, M.; Weiss, M.S.; Heinemann, U.; Mueller, U. XDSAPP: a graphical user interface for the convenient processing of diffraction data using XDS. J. Appl. Cryst.. 2012, 45, 568-572. [CrossRef]

19. Kabsch, W. XDS. Acta Cryst. 2010, 66, 125-132. [CrossRef] [PubMed]

20. Sheldrick, G.M. SHELXT-Integrated space-group and crystalstructure determination. Acta. Cryst. 2015, 71, 3-8. [CrossRef]

21. Brandenburg, K. DIAMOND, Release 2.1e.; Crystal Impact GbR: Bonn, Germany, 2001.

22. Farrugia, L.J. WinGX and ORTEP for Windows: an update. J. Appl. Cryst. 2012, 45, 849-854. [CrossRef]

23. Kumar, K.V.; Porkodi, K.; Rocha, F. Langmuir-Hinshelwood kinetics-A theoretical study. Catal. Commun. 2008, 9, 82-84. [CrossRef]

24. Abdellah, M.H.; Nosier, S.A.; El-Shazly, A.H.; Mubarak, A.A. Photocatalytic decolorization of methyleny blue using $\mathrm{TiO}_{2} / \mathrm{UV}$ system enhanced by air sparging. Alex. Eng. J. 2018, 57, 3727-3735. [CrossRef]

25. Frisch, M.J.; Trucks, G.W.; Schlegel, H.B.; Scuseria, G.E.; Robb, M.A.; Cheeseman, J.R.; Scalmani, G.; Barone, V.; Mennucci, B.; Petersson, G.A.; et al. Gaussian09, Revision D.01; Gaussian, Inc.: Wallingford, CT, USA, 2013; Available online: https:/gaussian.com/glossary/g09/ (accessed on 21 September 2019).

26. O’Boyle, N.M.; Tenderholt, A.L.; Langner, K.M. cclib: A library for package-independent computational chemistry algorithms. J. Comp. Chem. 2008, 29, 839-845. [CrossRef] [PubMed]

27. Addison, A.W.; Rao, T.N.; Reedijk, J.; van Rijn, J.; Verschoor, G.C. Synthesis, Structure, and Spectroscopic Properties of Copper(II) Compounds containing Nitrogen-Sulphur Donor Ligands; the Crystal and Molecular Structure of Aqua[1,7-bis(N-methylbenzimidazol-2'-yl)-2,6-dithiaheptane]copper(ii) Perchlorate. J. Chem. Soc., Dalton Trans. 1984, 1349-1356. [CrossRef]

28. Luo, W.; Ge, G. Two Titanium-oxo-Clusters with Malonate and Succinate Ligands: Single-Crystal Structures and Catalytic Property. J. Clust. Chem. 2016, 27, 635-643. [CrossRef]

29. Merrick, J.P.; Moran, D.; Radom, L. An evaluation of harmonic vibrational frequency scale factors. J. Phys. Chem. A 2007, 111, 11683-11700. [CrossRef]

30. Radtke, A.; Piszczek, P.; Muzioł, T.; Wojtczak, A. The Structural Conversion of Multinuclear Titanium(IV) $\mu$-Oxo-complexes. Inorg. Chem. 2014, 53, 10803-10810. [CrossRef]

31. Nakamoto, K. Infrared and Raman Spectra of Inorganic and Coordination Compounds, Part B: Applications in Coordination, Organometallic, and Bioinorganic Chemistry, 5th ed.; John Wiley \& Sons, Inc.: New York, NY, USA, 1997; pp. 172-173.

32. Wendlandt, W.W.; Hecht, H.G. Reflectance spectroscopy; Interscience Publishers: New York, NY, USA, 1966.

33. Nowak, M.; Kauch, B.; Szperlich, P. Determination of energy band gap of nanocrystalline SbSI using diffuse reflectance spectroscopy. Rev. Sci. Instrum. 2009, 80. [CrossRef] [PubMed]

34. Garza, A.J.; Scuseria, G.E. Predicting Band Gaps with Hybrid Density Functionals. J. Phys. Chem. Lett. 2016, 7, 4165-4170. [CrossRef]

35. Yao, J.; Wang, C. Decolorization of Methylene Blue with $\mathrm{TiO}_{2}$ Sol via UV Irradiation Photocatalytic Degradation. International J. Photoenergy 2010, 1-6. [CrossRef] 
36. Fatin, S.O.; Lim, H.N.; Tan, W.T.; Huang, N.M. Comparison of Photocatalytic Activity and Cyclic Voltammetry of Zinc Oxide and Titanium Dioxide Nanoparticles toward Degradation of Methylene Blue. Int. J. Electrochem. Sci. 2012, 7, 9074-9084.

37. Salehi, M.; Hashemipour, H.; Mirzaee, M. Experimental Study of Influencing Factors and Kinetics in Catalytic Removal of Methylene Blue with $\mathrm{TiO}_{2}$ Nanopowder. Am. J. Environ. Eng. 2012, 2, 1-7. [CrossRef]

38. Nattikran, Y.; Dang, T.T.T.; Duangdao, C.; Wilawan, K.; Auppatham, N. The influence of experimental conditions on photocatalytic degradation of methylene blue using titanium dioxide particle. J. of the Aust. Ceram. Soc. 2018, 54, 557-564. [CrossRef]

39. Liao, G.; He, W.; He, Y. Investigation of Microstructure and Photocatalytic Performance of a Modified Zeolite Supported Nanocrystal $\mathrm{TiO}_{2}$ Composite. Catalysts 2019, 9, 502. [CrossRef]

40. Mills, A.; Hill, C.; Peter, K.J.; Robertson, P.K.J. Overview of the current ISO tests for photocatalytic materials. J. Photochem. Photobiol. A: Chem. 2012, 237, 7-23. [CrossRef]

41. Nakamoto, K. Infrared and Raman Spectra of Inorganic and Coordination Compounds, Part A: Theory and Applications in Inorganic Chemistry, 5th ed.; John Wiley \& Sons, Inc.: New York, NY, USA, 1997; pp. 173-179.

42. Liu, G.; Yang, H.G.; Pan, J.; Yang, Y.Q.; Lu, G.Q.; Cheng, H.M. Titanium Dioxide Crystals with Tailored Facets. Chem. Rev. 2014, 114, 9559-9612. [CrossRef] [PubMed]

43. Mueller, U.; Förster, R.; Hellmig, M.; Huschmann, F.U.; Kastner, A.; Malecki, P.; Pühringer, S.; Röwer, M.; Sparta, K.; Steffien, M.; et al. The macromolecular crystallography beamlines at BESSY II of the Helmholtz-Zentrum Berlin: Current status and perspectives. Eur. Phys. J. Plus 2015, 130, 141-150. [CrossRef]

(C) 2019 by the authors. Licensee MDPI, Basel, Switzerland. This article is an open access article distributed under the terms and conditions of the Creative Commons Attribution (CC BY) license (http://creativecommons.org/licenses/by/4.0/). 